\title{
A review of solar energy based heat and power generation systems
}

\author{
Modi, Anish; Bühler, Fabian; Andreasen, Jesper Graa; Haglind, Fredrik
}

Published in:

Renewable \& Sustainable Energy Reviews

Link to article, DOI:

10.1016/j.rser.2016.09.075

Publication date:

2017

Document Version

Peer reviewed version

Link back to DTU Orbit

Citation (APA):

Modi, A., Bühler, F., Andreasen, J. G., \& Haglind, F. (2017). A review of solar energy based heat and power generation systems. Renewable \& Sustainable Energy Reviews, 67, 1047-1064.

https://doi.org/10.1016/j.rser.2016.09.075

\section{General rights}

Copyright and moral rights for the publications made accessible in the public portal are retained by the authors and/or other copyright owners and it is a condition of accessing publications that users recognise and abide by the legal requirements associated with these rights.

- Users may download and print one copy of any publication from the public portal for the purpose of private study or research.

- You may not further distribute the material or use it for any profit-making activity or commercial gain

- You may freely distribute the URL identifying the publication in the public portal

If you believe that this document breaches copyright please contact us providing details, and we will remove access to the work immediately and investigate your claim. 


\title{
A review of solar energy based heat and power generation systems
}

\author{
Anish Modi*, Fabian Bühler, Jesper Graa Andreasen, Fredrik Haglind \\ Department of Mechanical Engineering, Technical University of Denmark, Nils Koppels Allé, Building 403, \\ DK-2800 Kgs. Lyngby, Denmark
}

\begin{abstract}
The utilization of solar energy based technologies has attracted increased interest in recent times in order to satisfy the various energy demands of our society. This paper presents a thorough review of the open literature on solar energy based heat and power plants. In order to limit the scope of the review, only fully renewable plants with at least the production of electricity and heat/hot water for end use are considered. These include solar photovoltaic and solar thermal based plants with both concentrating and non-concentrating collectors in both solar-only and solar-hybrid configurations.

The paper also presents a selection of case studies for the evaluation of solar energy based combined heat and power generation possibility in Denmark. The considered technologies for the case studies are (1) solar photovoltaic modules, (2) solar flat plate collectors, (3) a ground source heat pump, (4) a biomass burner, and (5) an organic Rankine cycle. The various cases are compared on the basis of economic profitability and environmental performance. The results from the case studies indicate that it is economically and environmentally beneficial to invest in both small and large capacity solar-biomass hybrid plants for combined heat and power production in the Nordic climatic conditions. The results also suggest that the configuration with an organic Rankine cycle with solar thermal collectors and a biomass burner is particularly attractive for large capacity plants.
\end{abstract}

Keywords: Solar energy, Solar hybrid, Combined heat and power, Cogeneration, Denmark, Economic feasibility, Environmental performance

\footnotetext{
*Corresponding author. Tel.: +45 45251910

Email address: anmod@mek.dtu.dk (Anish Modi)
} 


\section{Introduction}

The five ultimate primary energy sources on the earth are (1) the sun, (2) geothermal energy, (3) the motion and the gravitational potential of the earth, the sun, and the moon, (4) human-induced nuclear reactions, and (5) the chemical reactions from mineral sources 5 [1]. Of these, the three renewable sources of energy are the sun, the geothermal energy from the earth, and the energy from the planetary motion. Among these, the incident power from the sun is the dominant renewable energy source. Even after excluding hydro power, biomass, and wind energy as indirect forms of solar energy, the amount of the incident solar radiation is still enormous. For this reason, the utilization of solar energy based technologies has attracted increased interest in recent times in order to satisfy the various energy demands of our society. These include, for example, electricity and heat $[2,3]$, refrigeration and cooling [4-6], industrial process heat [7], rural electrification [8], methanol production [9], hydrogen production [10], polygeneration container use during disaster and emergency situations [11], micro combined heat and power (mCHP) generation [12], desalination [13], various energy needs for agricultural greenhouses [14], and the improvement of the indoor environment conditions [15].

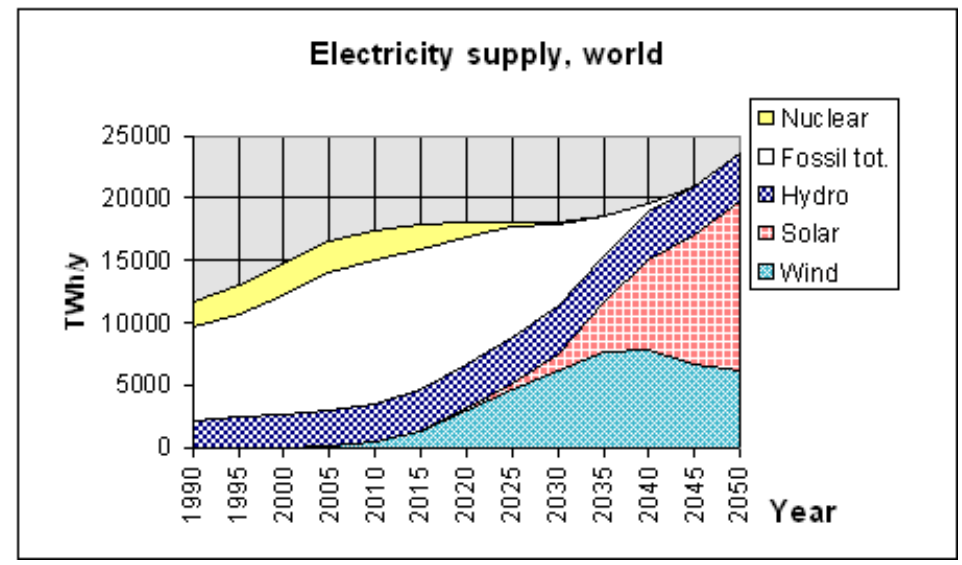

Figure 1: Global electricity supply - Vision 2050 [16]

For the residential consumers, electricity is the most important energy demand in most parts of the world. With regards to the generation of electricity, Fig. 1 presents a vision for satisfying the global electricity demand in 2050 with various energy sources [16]. In 
this vision, the solar energy based systems are predicted to occupy the highest share by the year 2050. Similarly, the International Energy Agency estimates that by the year 2050, the solar energy systems will be supplying about $17 \%$ of the global electricity demand in the 2 degree rise scenario, and about $27 \%$ in the 2 degree rise, high renewable energy mix scenario [17]. The 2 degree scenario means that the average global temperature rise should be kept below $2{ }^{\circ} \mathrm{C}$ as compared with the pre-industrial levels. In the high renewable energy mix scenario, the above share makes solar the dominant source for electricity. In several regions, other end products such as hot water, space heat, cooling, and potable water could be equally, or sometimes more important for the consumers than electricity. For example, the heat demand in residential buildings account for about $60 \%$ to $80 \%$ of the total energy demand in cold climates, while as high as about $30 \%$ to $40 \%$ in warmer climates [18]. In this regard, solar thermal systems are pertinent for (1) the countries which rely heavily on imported gas or oil to cover their heating demands, (2) the countries where increasing heat demand is covered using electrical boilers thereby straining the electricity grid, and (3) the countries with high cooling demand during sunny periods [18].

The Nordic countries have some of the highest per capita heating demands in the world. At the same time, these countries have also set ambitious climate and energy targets for the coming decades. These include Denmark setting a target of becoming a $100 \%$ renewable energy based society and Norway and Sweden seeking to reduce their greenhouse gas emissions by $100 \%$ by 2050 as compared with their respective 1990 emission levels [19]. For this reason, it is interesting for these countries to consider solar energy based systems in their energy portfolio. A huge interest in the solar energy systems for satisfying the heating needs is already evident from the enormous increment in the installed collector area for solar district heating projects, both small and large scale, that have come up in Scandinavia in the last decade [20]. Most of these district heating plants are however operated together with a natural gas boiler in order to satisfy the demand during the winter period when there is little sunshine. It is therefore interesting to evaluate the possibility of increasing the renewable share in providing both heat and electricity. In this regard, the combined heat and power (CHP) systems can prove to be highly useful in utilizing the locally available 
solar resource while effectively meeting the various consumer demands. In fact, the world's largest renewable energy based district heating plant with a significant share of solar energy in the energy input is the SUNSTORE4 plant in Denmark [21].

When it comes to the utilization of any energy source, particularly a renewable source, it is advantageous to operate with cogeneration or multigeneration [22, 23]. Classically, the term cogeneration has been used to represent the simultaneous generation of electricity and heat using a single fuel or energy source at a single site [24]. However, recently it has also been used to denote the generation of heat and cooling [25, 26], electricity and water [27, 28], electricity and cooling [29, 30], and electricity and hydrogen [31]. Therefore in order to avoid any confusion, the term combined heat and power (CHP) is used in this paper to represent the generation of electricity and heat from the same plant, but without restricting the energy input to a single energy source.

The primary objective of this paper is to present a thorough review of the open literature on solar energy based heat and power plants. To the authors' knowledge, such a review has never been done. Given the immense potential of the solar energy based CHP plants from both thermodynamic and economic perspectives, the paper also identifies relevant areas for further research. The review mainly focuses on the renewable plant configurations with at least electricity and heat/hot water as the end-user demands. An overview of the studies with plants generating additional products is also presented. Since the solar photovoltaic-thermal (PVT) systems have already been extensively reviewed [32-35], only the most recent reviews and research publications are discussed here. In the literature review, the various studies are grouped based on the energy input configuration, i.e. as solar-only or solar-hybrid energy input. An alternate overview, with the reviewed literature grouped based on the key technologies used in the various studies, is also presented in the Appendix. This includes the different power and CHP technologies, fuel cell related technologies, energy storage technologies, water purification technologies, and refrigeration, cooling, and heat pump related technologies.

The paper also presents some case studies in order to evaluate the potential of solar energy based CHP plants in Denmark considering both the solar photovoltaic (PV) and 
solar thermal systems for energy input. The considered cases are: (1) a base case with heat supply from a natural gas burner, (2) a solar PV assisted ground source heat pump (GSHP), (3) solar flat plate collectors with a GSHP, (4) solar flat plate collectors with a biomass burner, and (5) solar flat plate collectors with a biomass burner and an organic Rankine cycle (ORC). All the considered cases include a connection to the grid electricity with net metering. The various cases are compared based on their economic profitability and environmental performance. The annualized cost, i.e. the average annual amount spent on the plant including the investment and the operations and maintenance (O\&M) costs, is used to compare the different cases. The $\mathrm{CO}_{2}$ emissions for the different cases are also presented for comparison. All the cost figures are mentioned in Euros $(€)$.

\section{Literature review}

Solar energy based CHP systems can be used for satisfying multiple end-user demands and in either solar-only or in solar-hybrid configuration. The different possible configurations for the solar energy based CHP systems for residential consumers are shown in Fig. 2. The solid line on the energy conversion side represents a solar-only system which could be a PV, a PVT, or a solar thermal collector. At the same place, the dotted line represents a solar-hybrid energy conversion system where the solar collectors are operated together with other energy sources such as biomass, biofuels, wind energy, and the like. The primary outputs from these energy conversion mechanisms are electrical power and heat. These two outputs can then further be used in order to satisfy other residential consumer demands using additional technologies. For example, the electrical power output can be used to directly satisfy the electricity demands of the consumers, or it can also be used to operate a heat pump, a vapour compression refrigeration system, or a reverse osmosis plant. Similarly, the heat from the energy conversion systems can be used to satisfy the space heating or domestic hot water demands, or it can also be used as an input to an absorption chiller or a multiple-effect distillation plant. This paper mainly reviews the studies where at least electricity and heat/hot water are a part of the end-user consumption, but multigeneration [36] systems with additional products are also briefly discussed. 


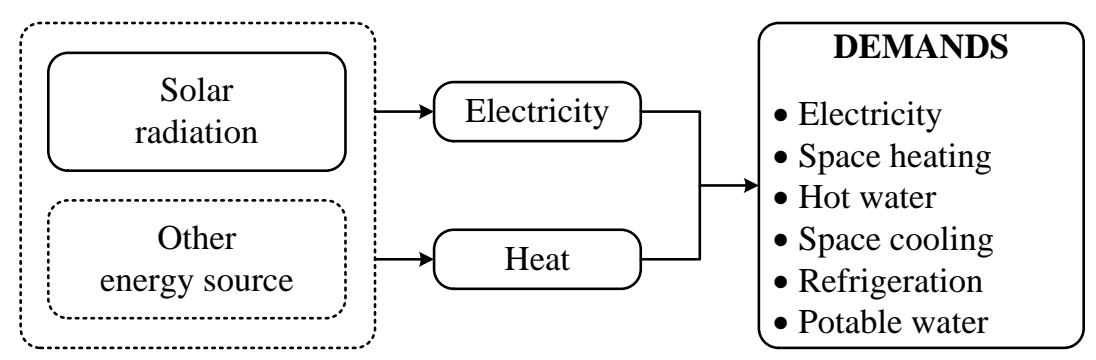

Figure 2: Possible configurations for the utilization of solar energy based CHP plants in order to satisfy various residential end-user demands.

\subsection{Solar-only energy input}

In this section, the plants with only solar energy as the input energy source are presented. These plants could either be solar PV based plants, including the PVT and concentrating photovoltaic-thermal (CPVT) collector systems, or could be solar thermal based plants with concentrating or non-concentrating collector systems.

\subsubsection{Solar PV, PVT, and CPVT based systems}

With the use of solar PV technology, the most researched way of supplying both electricity and heat is through the use of solar PVT systems [32, 33]. A solar PVT system consists of a PV panel where the heat generated by the PV panel while in operation is extracted by water, air, or a coolant, as shown in Fig. 3. Studies have also been conducted on the use of various solar energy technologies to drive heat pumps [37, 38], and for the PV systems to be used in conjunction with other technologies in order to supply both electricity and heat [39].

PV based systems. Franco and Fantozzi [38] presented an analysis of the use of solar PV panels and a GSHP for a residential building in Pisa, Italy. The house is also connected to the electrical grid in order to satisfy the consumer and heat pump electricity demand in case the PV plant fails to generate enough electrical power. The heat pump can be operated in either heating or cooling mode depending on the season. The results suggested that it is not possible to operate the plant independent of the grid even with a $3.7 \mathrm{~kW}$ PV array, particularly in the heating period. It is suggested that for an overall better energy efficiency, 
it might be relevant to size the heat pump at around $80 \%$ of the required nominal capacity. Nizetic al. [40, 41] presented an experimental and numerical evaluation of a hybrid energy system comprising of a solar PV plant supplying electricity and simultaneously running an air-conditioning system or a heater. The results demonstrated that the hybrid energy system could be implemented in countries with mild climates with heat pumps in order to achieve high seasonal coefficient of performance (COP) values. Thygesen and Karlsson [42] presented the analysis of the use of a novel weather forecast controller for a solar PV assisted heat pump in order to increase the self-consumption of the generated electricity by solar PV modules. The results suggested that the increment in the self-consumption was not enough to cover the additional costs for the controller. Shabani et al. $[43,44]$ presented a combination of solar PV panels with a proton exchange membrane fuel cell to satisfy the electricity and domestic hot water demand for a house in a remote location. The results indicated that over half of the domestic hot water demand may be fulfilled by utilizing the waste heat from the fuel cell and the excess hydrogen, while the rest of the demand may be satisfied by electricity or gas. Ahmadi et al. [45] presented the transient thermal performance assessment of a solar PV array based plant for the generation of electricity, heat, and cooling. The plant included an electrolyser, a fuel cell, a hydrogen tank, and an absorption chiller in addition to the solar panels.

PVT based systems. Elbreki et al. [34] and Good [35] have presented the most recent detailed reviews on the solar PVT technology and its hybridization with other systems, while Michael et al. [46] presented a reference guide for the flat plate solar PVT systems. Auzenet et al. [47] presented the results of energy, exergy, and economic analyses of coupling a solar PVT roof to a heat pump in a demonstration building highlighting the potential areas of improvement. Zafar and Dincer [48] presented a hybrid renewable energy system producing electricity, hot air, purified water, and hydrogen with a solar PVT array as the primary energy conversion device. In this system, the solar PVT array produces heat and electricity for residential consumption, while excess electricity is fed to an electrolyser for hydrogen production. The produced hydrogen could then be used to operate a fuel cell. The results suggested that significant economic gains could be made by utilizing the fuel cell heat and 


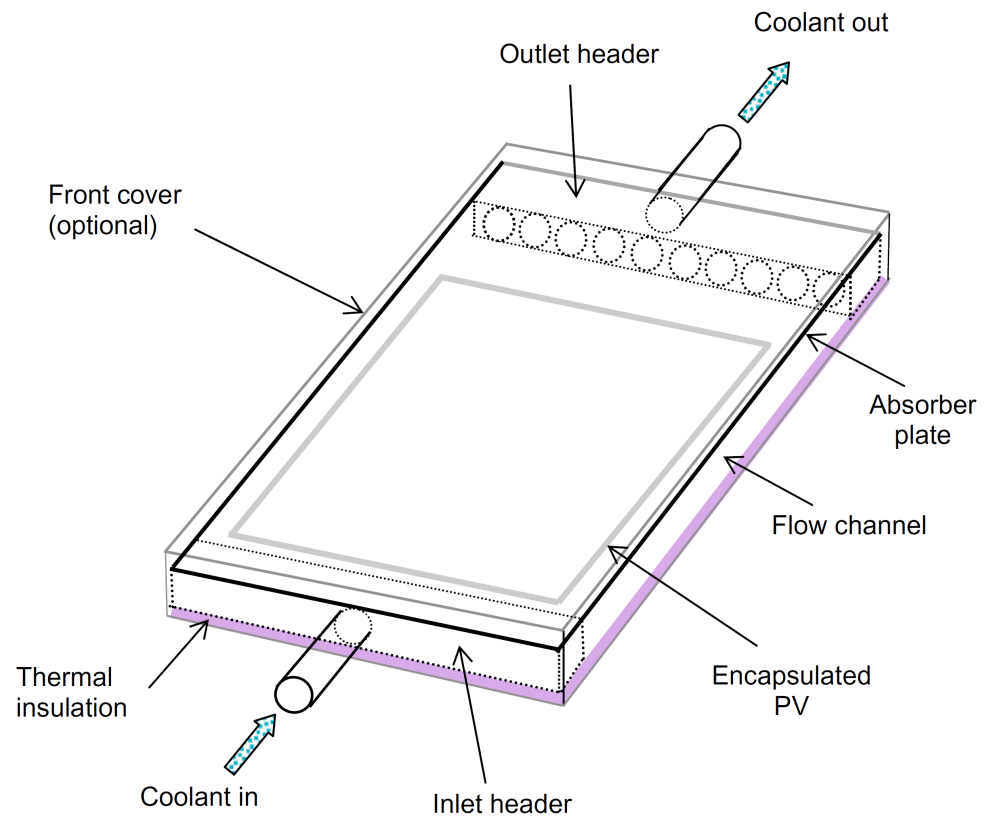

Figure 3: Solar PVT panel [32].

water as useful outputs. For a residential building with a swimming pool, Buonomano et al. [49] presented the results from the dynamic simulation and thermoeconomic analysis of a solar PVT array based renewable energy plant in Naples, Italy. The results suggested that by utilizing the available energy in multiple ways remarkably increases the overall energy efficiency, but in order to make the proposed system more economically attractive, supporting policies are needed.

CPVT based systems. Sharaf and Orhan $[51,52]$ presented a review of the CPVT solar collector systems. These systems could be used for production of both heat and electricity by concentrating the incident direct solar radiation on PV cells, while removing the heat from the cells with a coolant. An exemplary CPVT system is shown in Fig. 4. Buonomano et al. [53] presented the results from the design and dynamic simulation of a solar CPVT collector based polygeneration plant for a hospital building in Naples, Italy where the generated electricity was either consumed by the system parasitic loads or fed to the electrical grid. In addition to electricity, the plant also produced heat for space heating, domestic hot water, and/or cooling using an absorption chiller. More recently, Papadopoulos et al. [54] presented a review of the current status of the PV based power generation while introducing 


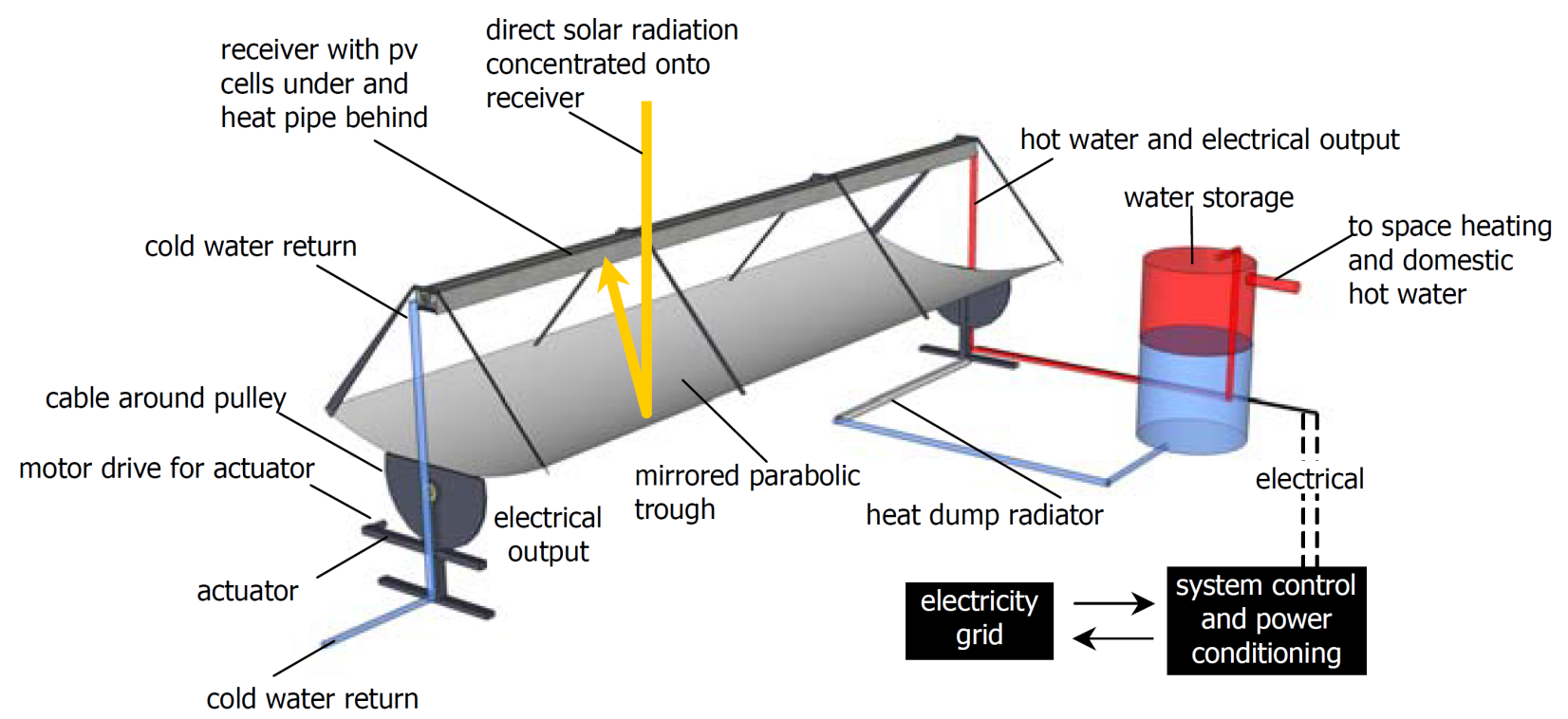

Figure 4: Solar CPVT system [50].

a solar polygeneration system based on an innovative design of the solar CPVT collector for simultaneous generation of electricity, hot water, and air-conditioning.

\subsubsection{Solar thermal based systems}

The solar thermal collectors and the plants using these collectors have been widely studied over the last few decades. These studies include analyses with both the concentrating and the non-concentrating collectors, and for various uses such as heating, cooling, and power generation. The studies include both solar-only and solar-hybrid configurations and even a combination of the solar thermal and solar PV systems. An overview of designing and developing thermodynamic cycles for concentrating solar plants both for only power generation and for CHP applications is presented by Kolios et al. [55]. Immovilli et al. [56] investigated solar trigeneration for residential applications as an alternative to the conventional microcogeneration and trigeneration plants. Ksayer [57] analysed an ORC with R245fa as the cycle working fluid for the production of electricity and hot sanitary water from low temperature solar heat $\left(120^{\circ} \mathrm{C}\right)$ for a typical dwelling in the Mediterranean region. Norwood et al. $[58,59]$ presented the life cycle analysis of a solar CHP plant in California, USA focusing on the economic, the global warming potential, and the water consumption aspects. 
Concentrating thermal collectors based systems. Crema et al. [60-62] presented the numerical and experimental study of a modular mCHP plant producing 1-3 kW electrical power and 3-9 $\mathrm{kW}$ thermal power using parabolic trough collectors with evacuated tube receivers and a Stirling engine. The plant was designed to provide electricity, heating, and cooling to single and multiple dwellings and other small buildings. Ferreira et al. [63] presented the results from a thermodynamic and economic optimization of a solar-powered Stirling engine with a solar parabolic dish for mCHP generation. A detailed optimization model (including the engine geometry) was presented. The main objective function was to maximize the annual worth of the cogeneration plant. Krüger et al. [64] built a parabolic trough solar field based plant capable of producing electricity, heat, and cooling on a small scale. A similar concept has also been investigated with an ORC unit and a two-tank thermal storage system $[65,66]$. Bouvier et al. $[67,68]$ presented the experimental characterization of a prototype of parabolic trough collectors with direct steam generation to be used in a $\mathrm{mCHP}$ plant in France. The initial results from the use of a steam engine with the parabolic trough collectors resulted in the generation of $18.3 \mathrm{~kW}$ of thermal power and $1.4 \mathrm{~kW}$ of electrical power. Abdelhady et al. [69] studied the design of a stand-alone small-scale solar thermal CHP plant for an isolated region in Egypt. The plant operated with parabolic trough solar field, a thermal storage system, and a steam Rankine cycle. The cost of electricity was found to be competitive when compared with the cost of expanding the electricity grid. The avoided greenhouse gas emissions were also estimated. Almahdi et al. [70] presented the analysis of a solar energy based multigeneration system with a parabolic trough solar field, two ORCs, a hot and a cold thermal energy storage system, an electrolyser, a heat pump, and two absorption chillers. The plant produced electricity, heat, space cooling, hydrogen, and dry biomass.

Naccarato et al. [71] presented the optimization of a small capacity ORC plant in Brindisi, Italy with $2 \mathrm{~kW}$ electrical power output with a parabolic trough solar field. The results indicated that the generation of both electricity and heat improved the overall plant efficiency from $12 \%$ to $30 \%$. Saadatfar et al. [72] modelled a solar thermal polygeneration plant producing power, heating, and cooling with a parabolic trough solar field and an ORC unit 
working with a nanofluid (n-pentane with silver nanoparticles) as the cycle working fluid. The results suggested that the achievable thermodynamic efficiency of the plant with the nano organic fluid is higher than that of the plant with the base fluid (n-pentane) under optimum conditions. The required heat exchanger areas were also smaller when using the nanofluid. Borunda et al. [73] analysed an ORC unit coupled with a parabolic trough solar field for a textile industrial process in Almeria, Spain. The results indicated that the analysed plant is a promising option for medium temperature applications where both heat and electricity are required as outputs. Ozlu and Dincer [74] analysed a multigeneration plant producing electricity, heating, cooling, and hydrogen using parabolic trough collectors, an absorption refrigeration cycle, a Kalina power cycle, an electrolyser, a hydrogen tank, and a thermal storage tank. The analysis was performed for a multi-unit building in Toronto, Canada and the results suggested that it is possible to maintain such a building or community with such a plant. Yuksel et al. [75] presented the results from a thermodynamic performance assessment of a solar energy based multigeneration plant. The plant operated with parabolic trough collectors, an ammonia-water power cycle, thermal storage tanks, a hydrogen storage tank, an electrolyser, a fuel cell, and an absorption cooling system, and produced electricity, hydrogen, hot water, heating, and cooling. Rabbani et al. [76] presented the transient energy and exergy analyses of a solar energy based plant in Toronto, Canada with a central receiver solar field, a gas turbine (operating with air Brayton cycle) and a reheat Rankine cycle producing electricity and hot water for domestic use. The highest exergy destruction was found to be in the molten salt receiver.

Non-concentrating thermal collectors based systems. Bocci et al. [77] presented the analysis of a plant producing electrical power, heat, cooling, and fresh water needs for a house in Rome, Italy. The plant included compound parabolic collectors, a thermal storage tank, an ORC, an absorption chiller, and a reverse osmosis desalination unit. Baral and Kim [78] presented an evaluation of 15 organic fluids for a solar ORC plant for CHP application in Busan, Republic of Korea. Flat plate solar collectors were analysed for the ORC plant with $90{ }^{\circ} \mathrm{C}$ as the hot fluid high temperature, whereas vacuum tube type solar collectors were analysed for the ORC plant with $125^{\circ} \mathrm{C}$ as the hot fluid high temperature. The ORC 
plant was analysed for $1 \mathrm{~kW}$ electrical power output, and among the compared fluids, the most suitable fluids were found to be R134a and R245fa for the $90{ }^{\circ} \mathrm{C}$ and the $125{ }^{\circ} \mathrm{C}$ ORC plants, respectively. Ziviani et al. [79] also presented a detailed analysis of using an ORC for low grade energy recovery such as from solar thermal collectors, but with a focus on the ORC part with both steady-state and transient analyses. Calise et al. [80] presented a transient analysis of a plant in Naples, Italy with evacuated tube collectors, a fuel cell, and a single-stage $\mathrm{LiBr}-\mathrm{H}_{2} \mathrm{O}$ absorption chiller. The results suggested that the plant is excellent from energy saving perspective, but significant public funding is required for it to become profitable for the end user. Twomey et al. [81] presented the results from the dynamic performance analysis of using a scroll expander in a small-scale solar CHP system for a large dwelling unit or a small commercial establishment in Brisbane, Australia. The plant operated with evacuated tube collectors and an ORC unit. It was suggested that the expander efficiency could further be improved by mechanical modifications such as improvements in the inlet and exit nozzle designs and improved lubrication. The energy produced by the plant was found to be sufficient to potentially cover the plant costs. Freeman et al. [82] analysed the performance of a domestic-scale CHP plant with solar flat plate collectors and an ORC for a typical UK home. Among the compared working fluids, HFC-245ca resulted in the highest net annual electrical work output. The results also suggested that the solar-only system could only satisfy about $32 \%$ of the annual electricity demand.

A number of studies have also been performed with a $\mathrm{CO}_{2}$ based Rankine cycle powered by solar energy for CHP production. Zhang et al. [83-88] presented the numerical and experimental analysis of a transcritical $\mathrm{CO}_{2}$ Rankine cycle for CHP application. The cycle included evacuated tube solar collectors, a power turbine, a heat recovery system, and a feed pump. It is shown in Fig. 5. The results suggested that the investigated cycle has a good potential for use as a distributed energy supply system. Kuwahara et al. [89] experimentally investigated a similar cycle but with a novel thermally driven pump, and where the recovered heat may also be used for air-conditioning loads in addition to the hot water demands. Chen et al. [90] studied a small-scale solar-driven $\mathrm{CO}_{2}$ plant for CHP production in Sweden. The simulation results suggested that the studied system is a promising solution for the utilization 


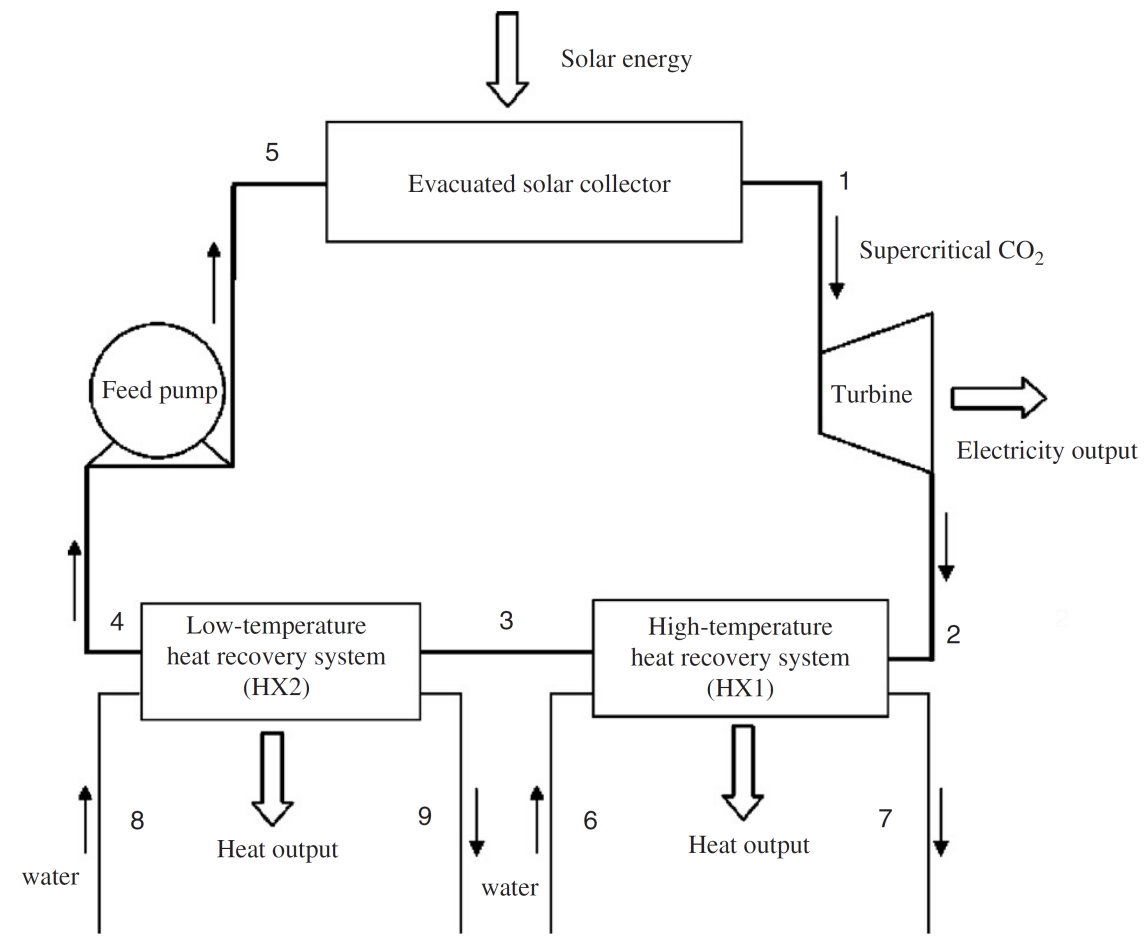

Figure 5: A transcritical $\mathrm{CO}_{2}$ Rankine cycle powered by solar energy for CHP applications [83].

of low grade heat.

\subsection{Solar-hybrid energy input}

In this section, the plants with hybrid energy sources as the input are presented. These include solar energy based plants with biomass, geothermal, or wind energy as supplementary energy sources. The presented plants are based on both solar PV and solar thermal collectors.

\subsubsection{Solar-biomass hybrid systems}

The most studied hybridization alternatives for renewable solar-hybrid plants are solar-biomass or solar-biofuel based energy conversion systems.

PV, PVT, and CPVT based systems. Brinkmann [91] presented the analysis of a solar PV and biomass hybrid plant linked with a steam engine to generate electricity and heat for private households in Germany. The analysis highlighted that the capability of the whole system to follow the dynamic characteristics of the energy demand is important for effective operation. Hosseini et al. [92-94] investigated a CHP plant in Toronto, Canada 
with solar PV-biomass system with a fuel cell and energy storage. The biomass was used to produce syngas which was fed to a gas turbine. The plant produced electricity together with heat for district heating.

The use of solar CPVT systems in hybrid configuration has been studied for desalicollector loop choice. Borello et al. [100] investigated an advanced small-scale CHP plant for a typical hotel in Rome, Italy. The plant operated with a Rankine cycle with energy input from a parabolic trough solar field and a biomass furnace. The plant also included a 

with the electrical and the thermal energy demands for different load tracking scenarios. The results showed the CHP plant presented an energy saving possibility as compared with having separate plants for the generation of electricity and heat, but with a higher capital investment cost. Sterrer et al. [101] presented a theoretical analysis of a CHP plant with parabolic trough solar field, biomass combustor, and an ORC unit with a nominal electrical power output of 1.5 MW. The plant performance was investigated for operation in Austrian climatic conditions. The heat from the plant was used in district heating. The primary reason to couple a solar field to the biomass based CHP plant was to reduce the biomass consumption of the plant. It was highlighted that a feed-in-tariff for solar thermal electricity similar to that for the solar PV plants could trigger the retrofit of biomass based CHP plants in Central Europe.

Desideri et al. [102] presented the dynamic modelling and control strategy analysis of a small solar-biomass hybrid plant in Cacares, Spain with a parabolic trough solar field, a biomass combustor, and an ORC unit producing electricity and heat for a building. A comparison was made between two operating strategies, the partial defocusing and the total defocusing of the solar field during a constant low thermal demand from the building. It was found that the total defocusing approach resulted in a 12 percentage point higher solar fraction than the partial defocusing approach. Karellas and Braimakis [103] presented the thermodynamic modelling and economic analysis of a micro-scale plant in Greece capable of operating either as a cogeneration or a trigeneration plant. The plant included a parabolic trough solar field and a biomass combustor and operated with an ORC unit and a vapour compression refrigeration cycle. The results indicated that even for the worst case scenario assumptions, the plant exhibits positive economic results. Burin et al. [104] analysed a CHP plant producing electricity and industrial process heat by adding a parabolic trough solar field to a biomass based CHP plant located in Brazil in order to improve the overall capacity factor. The solar field was used for feedwater heating. One of the main advantages highlighted was the minimal modifications required to the existing plant for adding the solar field. It was also highlighted that a year round operation is necessary to improve the 
economic feasibility of the hybridized plant. Burin et al. [105] continued the analysis and centrator which delivered high temperature heat to an ammonia-water Rankine cycle. The Rankine cycle produced useful work and delivered useful heat to a heat sink. The results 


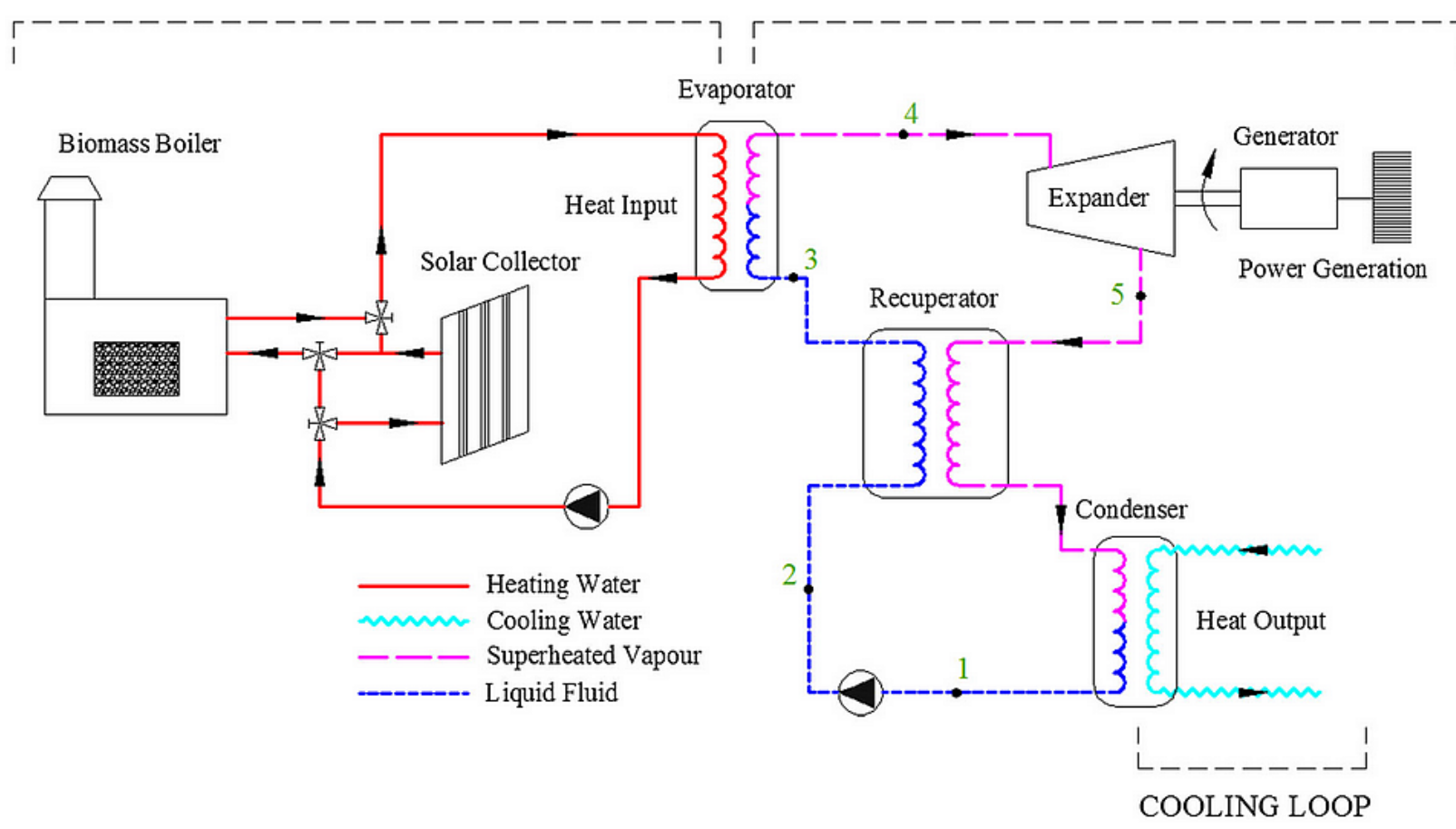

Figure 6: A regenerative ORC unit with a solar-biomass hybrid energy input for production of power and heat [110].

showed that it is possible to mitigate 3-4 times more $\mathrm{CO}_{2}$ than a PV system, but in order for these systems to be economically attractive, supportive economic policies such as carbon tax and feed-in-tariff programs are necessary. Angrisani et al. [113] proposed a unique solar-biomass hybrid CHP plant based on a Stirling engine and a fluidized bed combustor. In the plant, the direct solar irradiation was concentrated on the fluidized bed working as the solar receiver using a Scheffler type mirror. A high investment cost was pointed out as the main drawback of such a plant. Khalid et al. [114] analysed a solar-biomass integrated plant for the generation of electricity, heat, and cooling. The energy input to the plant came from a central receiver solar field and a biomass based combustion chamber for a gas turbine. The overall energy and exergy efficiencies for the hybrid plant were respectively found to be $66.5 \%$ and $39.7 \%$, as compared with $64.5 \%$ and $37.6 \%$ with only the biomass part operating, and $27.3 \%$ and $44.3 \%$ with only the solar part operating. Efendiev et al. [115] presented several cases operating with solar energy and biogas based systems considered 
for farms and small holdings in Russia which are at a considerable distance from the local energy networks from economic perspective.

\subsubsection{Solar-geothermal hybrid systems}

PV, PVT, and CPVT based systems. Calise et al. [116] presented the results from the dynamic simulation and economic assessment of a solar and geothermal energy based polygeneration plant for simultaneous production of electricity, thermal energy, cooling energy, and fresh water. The plant included solar CPVT collectors, an absorption chiller, a desalination unit, and storage tanks. The plant was analysed to be used on small volcanic islands in the Mediterranean Sea. The results indicated that the economic attractiveness of such a plant increases significantly with the rise in the domestic hot water demand. Bicer and Dincer [117] analysed and evaluated a solar PVT and geothermal based multigeneration plant producing electricity, heat, cooling, hot water, and drying air for food drying in a farm in Canada. The plant also included an ORC unit, an absorption cooling system, and thermal energy storage. The results suggested that the mass flow rates within the subsystems have a significant impact on the overall system performance, and the evaporator and the turbine in the ORC unit have the highest exergy destruction rates.

Thermal collectors based systems. Tempesti et al. [118, 119] analysed mCHP plants operating in Florence, Italy with solar and low temperature geothermal energy. The plants were analysed for small capacity CHP production, e.g. for buildings with 30-40 apartments. One of the analysed plant layouts, with a single pressure ORC unit, is shown in Fig. 7. This layout operates with evacuated tube solar collectors. Another analysed layout was a dual pressure ORC unit with a parabolic trough solar field for superheating the ORC working fluid at the high pressure. The results indicated that the single pressure layout performed better than the dual pressure layout, and among the compared ORC working fluids, the plant with R245fa is the least expensive. Ruzzenenti et al. [120] evaluated the environmental sustainability of a solar-geothermal mCHP plant operating with an ORC unit in Pisa, Italy. Only evacuated tube solar collectors were included in the plant. A life cycle analysis was performed in order to evaluate the plant performance. The results suggested 


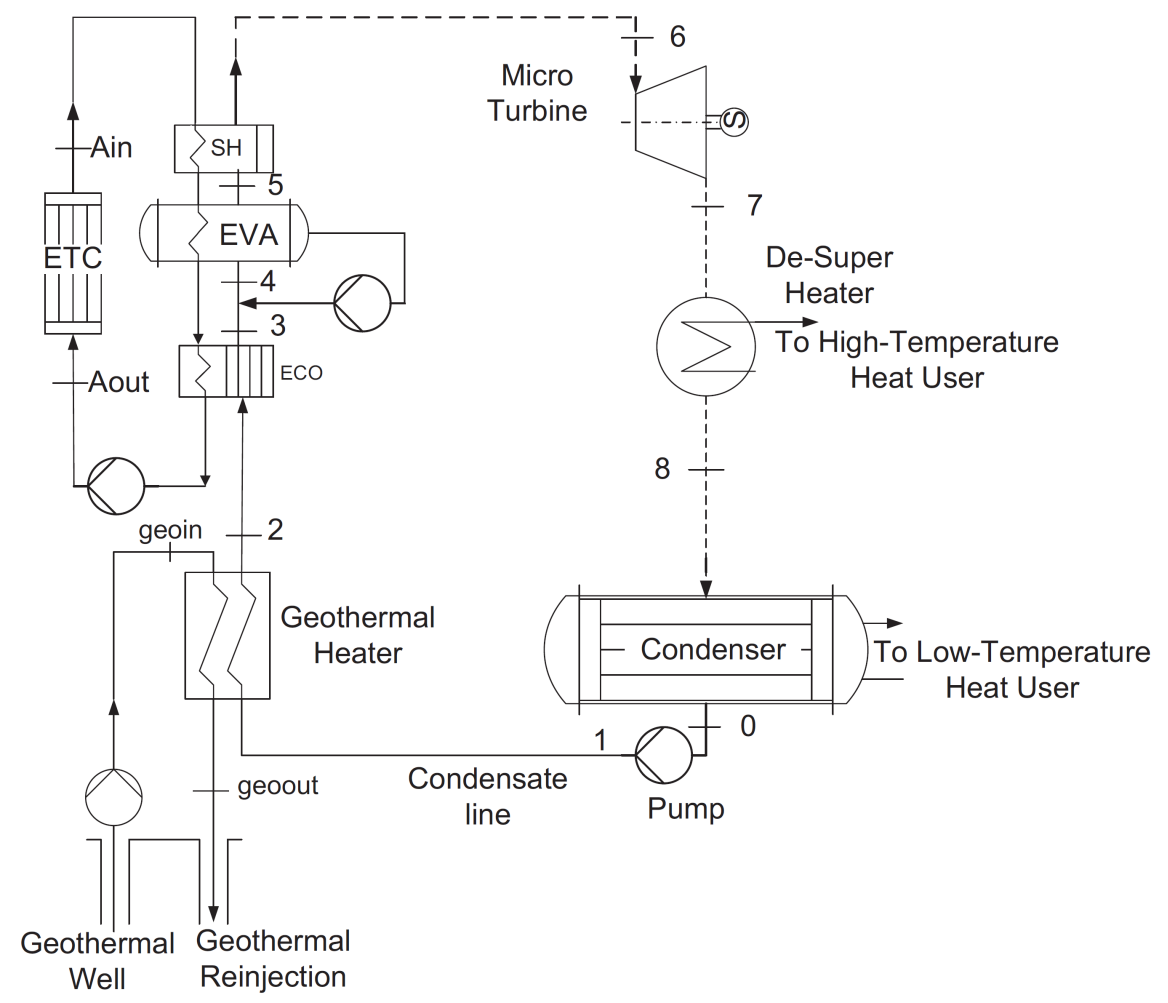

Figure 7: A low temperature solar-geothermal hybrid CHP plant with an ORC [119].

that from a sustainability perspective, the plant needs to develop existing wells which were previously abandoned rather than creating new ones.

Al-Ali and Dincer [121] presented the energy and exergy analyses for a multigeneration solar-geothermal hybrid plant. The analysed plant included a parabolic trough solar field, a single absorption chiller, and an ORC unit, and produced electricity, cooling, space heating, hot water, and industrial process heat. The results indicated that nearly $75 \%$ of the exergy destruction occurs in the solar field. A similar plant was investigated by Suleman et al. [122] using energy and exergy analyses. Calise et al. [123] presented the dynamic simulation and exergoeconomic optimization of a solar-geothermal CHP plant for a hotel in Italy. The plant included a parabolic trough solar field, an ORC unit, and a storage tank in addition to the geothermal cycle. The results indicated that the costliest components of the plant were the solar collectors and the ORC unit. It was also found that the production of thermal energy is crucial for economic profitability. Calise et al. [124] presented the exergoeconomic 


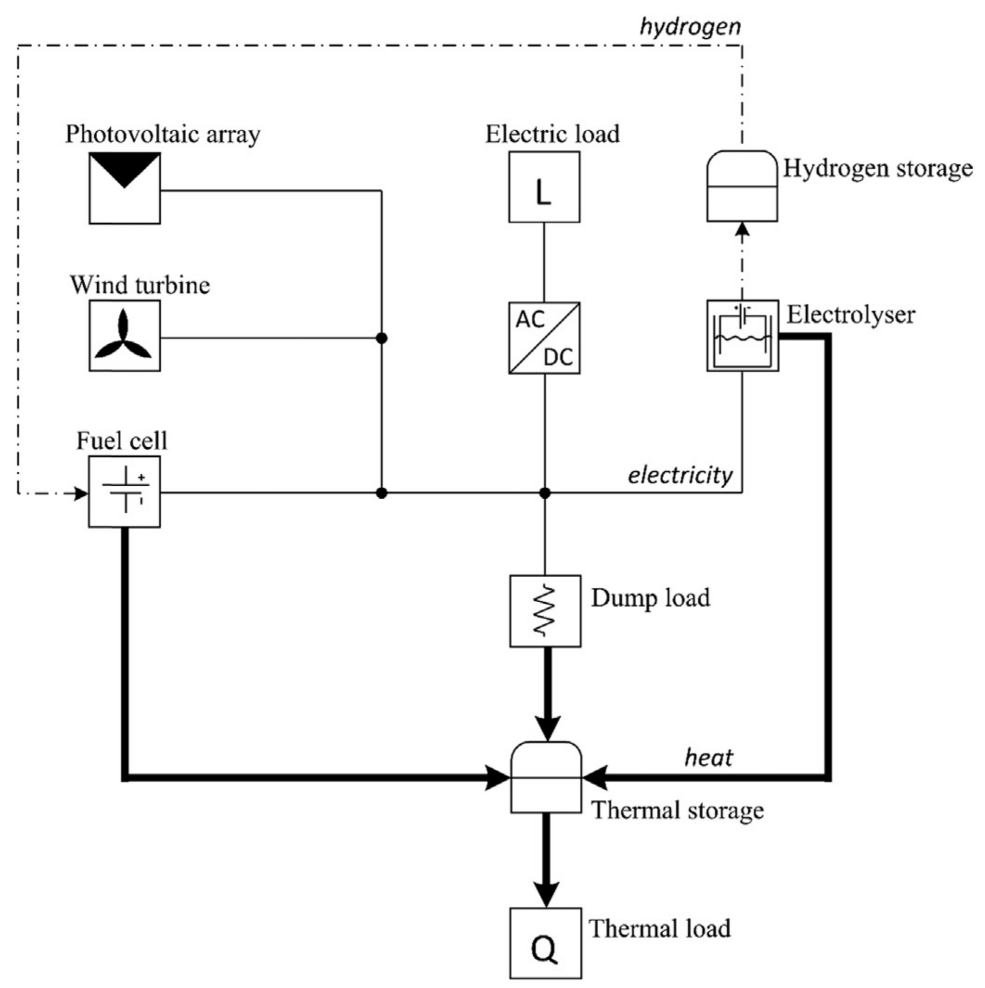

Figure 8: A fully renewable CHP plant based on solar PV and wind energy technologies including a fuel cell, an electrolyser, a hydrogen storage system, and a thermal storage [125].

analysis of a solar-geothermal hybrid plant producing electricity, heating, cooling, and fresh water. Based on their system design, the results suggested a competitive price for clean water production, but not so much for electricity.

\subsubsection{Solar-wind hybrid systems}

A few studies have also investigated the hybridization of solar and wind energy technologies for CHP plants. Lacko et al. [125] analysed a solar PV and wind turbine hybrid system including a fuel cell, an electrolyser, a hydrogen storage system, and a thermal storage for the production of electricity and heat for stand-alone applications such as isolated households in Slovenia. The studied system is shown in Fig. 8. The results indicated that the investigated fully renewable CHP plant is both technically feasible and more cost-effective, when considering both the capital investment and the O\&M costs, as compared with a system utilizing fossil heat. Rouholamini and Mohammadian [126] also investigated a similar CHP 
plant, but for a grid-connected application in Iran. This plant included a solar PV array, a wind turbine, a polymer exchange membrane fuel cell, an electrolyser, an electric heating system, and a hydrogen tank. Ozlu and Dincer [127] analysed a multigeneration system with parabolic trough collectors, a wind turbine, a steam Rankine cycle, an absorption chiller, and an electrolyser for the production of electricity, domestic hot water, cooling, and hydrogen. The efficiency of the multigeneration system was found to be higher than the combined efficiency of a plant with separate units. Khalid et al. [128] presented the techno-economic assessment of multigeneration plant for green buildings. The plant included a wind turbine, parabolic trough solar collectors, an ORC unit, a storage tank, an absorption chiller, and a GSHP. The plant produced electricity, hot water, heating, and cooling.

\subsection{Other studies}

The combination of solar PV and solar thermal collectors as the source of energy input to the CHP plant has also been investigated by some researchers. Ahmadi et al. [129, 130] presented a multi-objective optimization and performance assessment of a solar and ocean thermal energy conversion plant for the production of electricity, heating, cooling, hydrogen, fresh water, and hot water in coastal areas. The plant included solar PVT collectors, flat plate collectors, a reverse osmosis desalination unit, a single-effect absorption chiller, an ocean thermal energy conversion cycle, and a proton exchange membrane electrolyser. The results suggested that the exergy efficiency and the total plant cost increased with an increase in the PVT collector length and inlet air mass flow rate, the turbine and the pump isentropic efficiencies, and the absorption chiller evaporator temperature. Akikur et al. [131, 132] presented the performance analysis of a CHP plant in Malaysia with a parabolic trough solar field, solar PV array, a solid oxide fuel cell, a thermal storage system, and hydrogen and water storage tanks. The results indicated that the cost of solar energy and solid oxide fuel cell based power generation is higher than that from the fossil fuel based system, hence requiring subsidy or other incentives for becoming economically attractive. Sanaye and Sarrafi [133] presented the energy, exergy, and economic optimization of a grid-connected solar energy based plant for the production of electricity, heat, and cooling. The plant 
included a solar PV array, solar CPVT collectors, evacuated tube collectors, an absorption chiller, a battery bank, and a hot water storage tank. The results indicated that the use of a battery bank was not justified because of the small difference between the price of the generated and the purchased electricity.

Islam et al. [134] presented the energy and exergy analyses for a solar energy based multigeneration plant including thermoelectric generators. The plant was driven by a solar PV array and parabolic trough collectors, and included a thermoelectric generator/cooler, an ORC unit, an absorption chiller, a thermal energy storage system, and a heat pump. The plant produced electricity, domestic hot water, heat, cooling, and hydrogen. The results suggested that the highest irreversibility was observed in the parabolic trough solar field, followed by the absorption chiller. Yilmaz et al. [39] investigated a grid-connected solar PV array and a solar water heater based plant for providing electricity and hot water to a school in Turkey. The plant also included an air heat pump and a storage tank. The results suggested that the entire energy needs of the school may be satisfied by the plant with optimal planning. Assaf and Shabani [135] presented a transient analysis of a stand-alone solar-hydrogen CHP plant for a remote household in Australia. The plant included a solar PV array, solar thermal collectors, an electrolyser, a fuel cell, a hydrogen storage tank, and one or two water storage tanks. The simulated plant was found to be capable of satisfying the annual heat and electrical power demand almost fully.

A combination of reversible heat pumps and ORC plant has also been investigated for the production of electricity and heat. These types of plants are capable of producing both electricity and heat for residential uses, but not necessarily simultaneously. Dumont et al. [136] and Quoilin et al. [137] investigated a reversible heat pump and ORC based plant for domestic application. The plant included roof-mounted solar thermal collectors, a ground heat exchanger, a storage tank, and the reversible heat pump and ORC unit. The plant could be operated in a direct heating mode, a heat pump mode, or an ORC mode. The plant was investigated both numerically and experimentally. Several improvements were suggested to improve the performance of such a plant based on the experimental observations. Schimpf 
operation reduces the net electricity demand from the grid while mitigating the potentially harmful stagnation of the solar collector loops in a cost-effective way.

Another interesting area of research using solar energy based systems is towards developing a green building or a zero energy building [140]. In this regard, Dagdougui et al. [141] modelled and optimized a hybrid system for the energy supply of a green building including both the electrical and the thermal demands. The energy input was from solar flat plate collectors, a solar PV array, a biomass unit, and a wind turbine. Good et al. [142] compared the use of solar thermal, solar PV, and solar PVT collectors for net zero energy buildings. The plant also included a hot water storage tank and an air to water heat pump. Hassoun and Dincer [143] analysed the performance of a multigeneration plant for a net zero energy house in Lebanon. The plant included solar collectors, an ammonia-water Rankine cycle, an electrical and battery system, and a hot water tank among other components. Oliveira [144] studied a building facade using solar energy to generate electricity, heating, or cooling by combining solar PV cells with a solar air collector and a thermoelectric heat pump into a compact building envelope solution. The use of thermoelectric systems has also been investigated by Omer and Infield [145], Miljkovic and Wang [146], Nia et al. [147], and Ong [148]. Some novel ideas include the use of a solar chimney based CHP plant with solid oxide electrolyser and fuel cell systems along with a hydrogen storage tank [149], and the use of photon-enhanced thermionic emission where the residual heat may be used for low temperature power generation and/or satisfying the heat demands [150]. Ghosh and Dincer [151] analysed a plant with multiple energy sources for energy input producing electricity, heating, cooling, and fresh water. The plant operated with solar, wind, and geothermal energy, and included a parabolic trough solar field, a wind turbine, a steam Rankine cycle, an absorption chiller, and a reverse osmosis unit. The plant overall energy and exergy efficiencies were found to be $36.7 \%$, and $25.07 \%$, respectively.

\subsection{Discussion}

The utilization of solar energy for heat and power generation has recently attracted increased interest as is evident from the significant number of research publications in the 
last 4-5 years. This interest comes from many reasons such as utilizing a local energy source which is freely available, reducing the dependency on fossil fuels, or even reducing the consumption of biomass through hybridization [101]. Most of the research has been conducted for residential scale consumers, but several other plant scales have also been analysed such as schools [39], hospitals [53], multi-unit dwellings [74], industrial processes [73, 104, 121], hotels [100, 123], district energy supply [92-94, 101], and specific end-uses such as swimming pool heating [49]. Since evaluating the possibilities for fully renewable solar energy based CHP plants is a recent field of research, the main focus until now has been on evaluating suitable plant configurations for different locations around the world. The various studies have evaluated the possible configurations on both the energy input (through hybridization) and the energy output (multiple end products) sides. A location specific study in this context is important since the renewable sources could vary significantly from one region to another. For this reason, the combination of solar energy with biomass, wind energy, and/or geothermal energy depends on where the plant will be located. For the plants where solar energy is hybridized with biomass or geothermal energy sources, it was more common to evaluate configurations without any other external storage systems or with only buffer storage systems. This is because biomass and geothermal energy provide a more reliable continuity from the source side. On the other hand, for the solar-only or solar-wind hybrid plants, it has been common to analyse the plant configurations with fuel cells and hydrogen storage tanks or other storage possibilities because of the more intermittent nature of these energy sources.

In general, many of the evaluated technologies (see Appendix) are already available for commercial deployment. These include power generation plants with steam Rankine cycle, Brayton cycle, or ORCs, refrigeration plants with vapour compression or absorption cycles, heat pumps, small capacity fuel cells, and thermal storage systems. The key research aspects of the literature analysing plants with these technologies lay in evaluating the different possible combinations and configurations that could meet the various end-user demands in a cost-effective manner. In this regard, the results suggest that the plants with solar energy as the only source of energy input and without any storage are incapable of satisfying 
the consumer heat and power demands, mainly because of the mismatch between the solar energy availability and the consumer demand patterns [38, 43, 44, 82]. Most likely, a connection to the electricity grid might be required for balancing out the electricity demand and an auxiliary heater might be required in order to counter the unsatisfactory winter performances [95].

Most of the studies have analysed the various plant configurations from thermodynamic design perspectives, but there are some studies which have also considered the economic aspects. In this regard, the general consensus is that the fully renewable solar energy based heat and power plants would require additional support policies in order to become economically attractive [49, 95]. Examples of such policies could be public funding [80], feed-in-tariff [101], carbon tax [112], or subsidies [131, 132]. The economic challenges exist mainly because of the expensive components such as the solar collectors and other small capacity technologies such as the ORC units and fuel cells. This has also been the motivation behind analysing the plant configurations with additional outputs (such as cooling and fresh water) in order to justify the high capital investment costs, and to look into various options for storage (thermal, hydrogen, electrical, and compressed air). Nevertheless, there are some exceptional cases where the cost of electricity was found to be higher for the grid expansion than from a solar plant [69], or when the fully renewable solar CHP plant was found to be more cost-effective than a fossil fuel based plant over the operational lifetime [125].

\section{Case studies for Denmark}

The utilization of solar energy systems for the generation of electricity and heat, not necessarily as CHP, has seen immense rise in Denmark and other Nordic countries in the last decade. Research has been conducted for solar PV systems with regards to adapting the PV cells and modules for operating in the Nordic climatic conditions $[152,153]$ and evaluating their potential for grid connected applications [154, 155]. A large number of solar thermal systems have also been installed, particularly for district heating applications [20, 156]. It is therefore relevant to identify the various configurations which could provide heat and electricity to the Danish consumers in a sustainable manner. The most known solar 
technologies for the consumers in Denmark are the solar PV systems for residential and small capacity stand-alone uses and the non-concentrating solar thermal collectors for residential and district heating plants. Additionally, biomass based energy conversion systems are also commonly used for both large and small capacity heating and CHP plants. For small capacity decentralized CHP plants, the ORC technology has recently attracted increased interest in Denmark. The first Danish ORC unit $\left(750 \mathrm{~kW}_{\mathrm{e}}\right)$ was installed as a part of the SUNSTORE4 plant on the small Danish island Ærø [21], where it works in combination with solar thermal collectors, a pit heat storage system, and a heat pump. Additionally, a $4.2 \mathrm{MW}_{\mathrm{e}}$ biomass based ORC CHP plant is currently under construction [157], while a biomass and parabolic trough solar field based ORC CHP plant has recently been commissioned [158]. Between 1990 and 2014 the use of biomass in the energy sector increased by $90 \%$ [159]. For district heating, the use of woody biomass alone has increased from 324 TJ to more than 20000 TJ in the same time frame. Similarly, heat pumps such as GSHPs have also experienced a significant increase in usage in the last few decades. Heat supplied by heat pumps has increased by $220 \%$ between 1990 and 2014 in Denmark, producing 7200 TJ of heat in 2014 [159]. Therefore, a solar PV array, solar flat plate collectors, a biomass burner, a GSHP, and an ORC unit are the considered technologies in the analysis presented here.

\subsection{Cases}

Table 1: Cases considered for a preliminary evaluation of solar energy based CHP plants in Denmark. A connection to the electricity grid is assumed for all the mentioned cases.

\begin{tabular}{ll}
\hline Case & Description \\
\hline Base case & Heat supply from a natural gas burner \\
PV-HP & Solar PV assisted GSHP \\
FPC-HP & Solar flat plate collectors with a GSHP \\
FPC-BIO & Solar flat plate collectors with a biomass burner \\
FPC-ORC & Solar flat plate collectors with a biomass burner and an ORC unit \\
\hline
\end{tabular}


Table 1 shows the various cases considered for a preliminary evaluation of the solar energy based CHP plants in Denmark. The various cases are compared based on their economic profitability and environmental performance. In order to compare the solar case studies to conventional systems used for residential areas not connected to the district heating network in Denmark, a base case, with the houses connected to the electrical grid and a natural gas burner, was considered. The case with a solar PV assisted GSHP and a connection to the electricity grid (PV-HP) is shown in Fig. 9. The GSHP is used to cover the thermal energy demand, while the electrical energy demand is covered by solar PV array and grid electricity. It was assumed that net metering allowed the plant to fully utilize the energy generated by the solar PV array without the need for an electrical energy storage system.

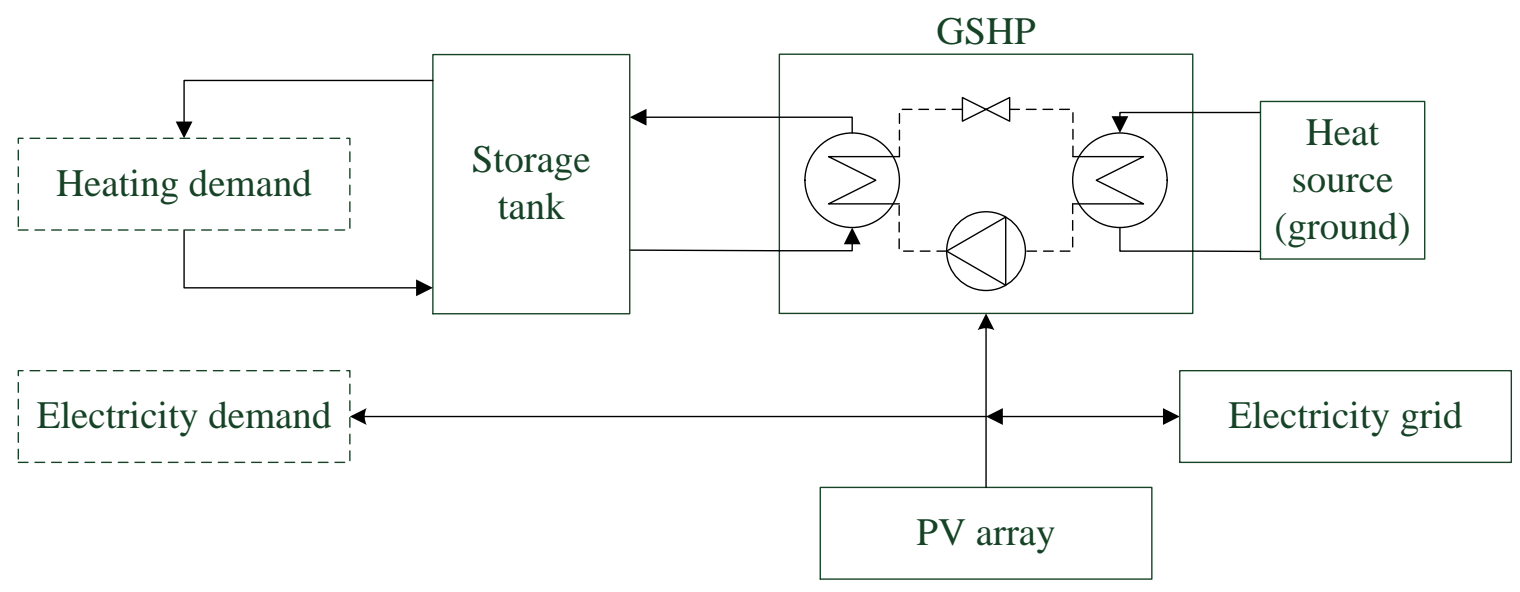

Figure 9: Case 'PV-HP' with a solar PV array and a GSHP. 


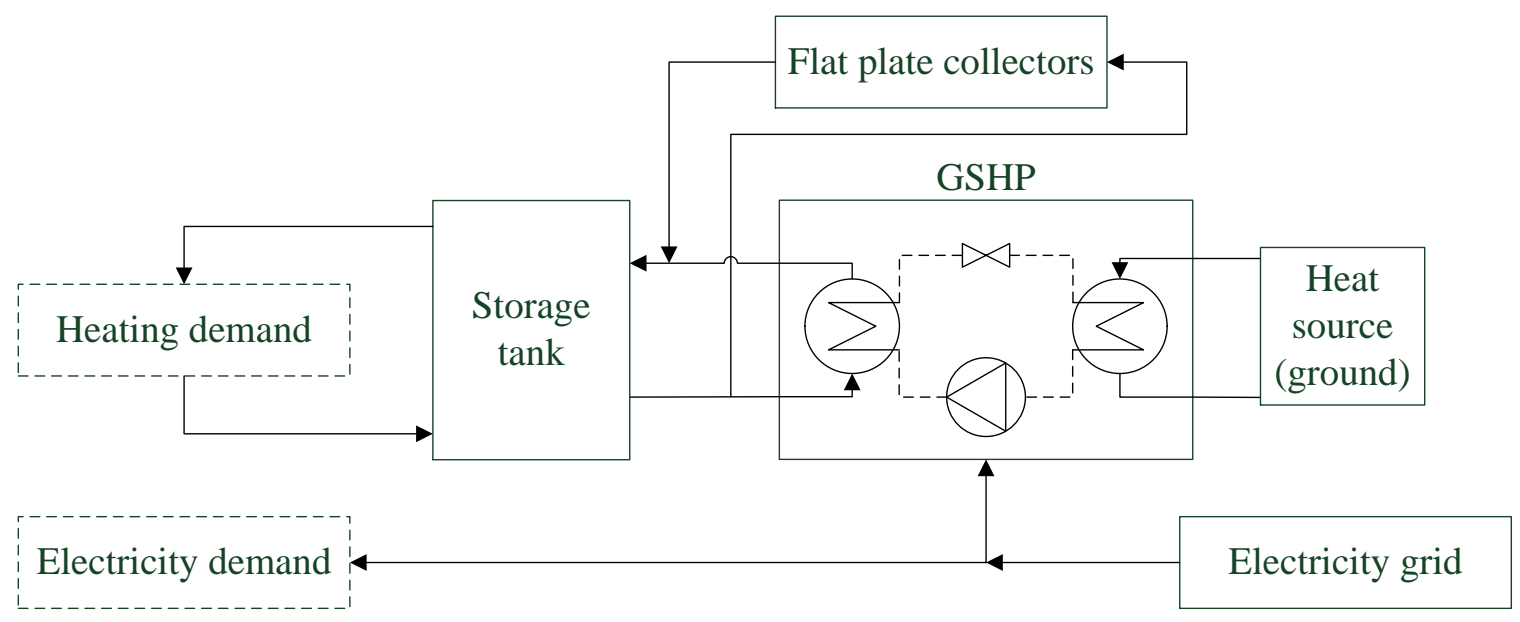

Figure 10: Case 'FPC-HP' with solar flat plate collectors and a GSHP.

The configuration for the case FPC-HP is shown in Fig. 10. In this case, the heating demand is covered with solar thermal flat plate collectors and a GSHP, while the electrical energy demand is met by grid electricity. For the GSHP, which covers all heating demand not supplied by the solar collectors, the same seasonal COP values are chosen as for the PV-HP case. The case FPC-BIO is shown in Fig. 11. In this case, the heating demand is supplied by solar flat plate collectors and a biomass burner, while the electricity demand is satisfied fully by a connection to the electrical grid. The biomass burner operates on wood pellets with low moisture content and high density, which are also easily transportable and storable. The last case, FPC-ORC, is shown in Fig. 12. It consists of solar flat plate collectors, a biomass burner, and an ORC unit. When the heating demand is not covered by solar energy, the evaporator of the ORC unit is supplied with heat from the biomass burner. On the condenser side, heat is supplied to the houses. The electricity produced from the ORC unit is, via net metering, used to cover the electricity need of the households. 


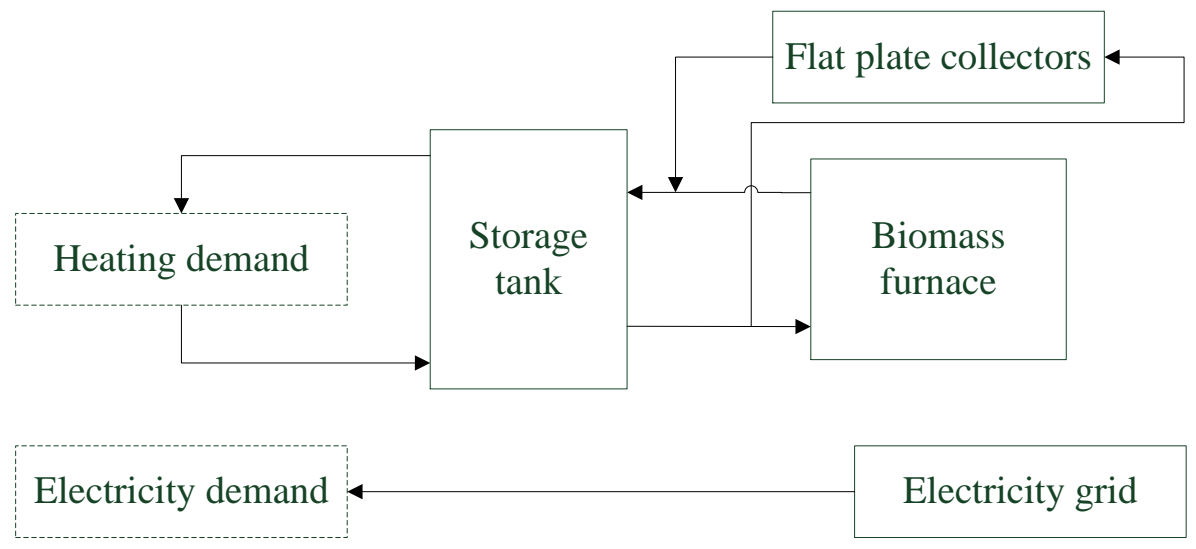

Figure 11: Case 'FPC-BIO' with solar flat plate collectors and a biomass burner.

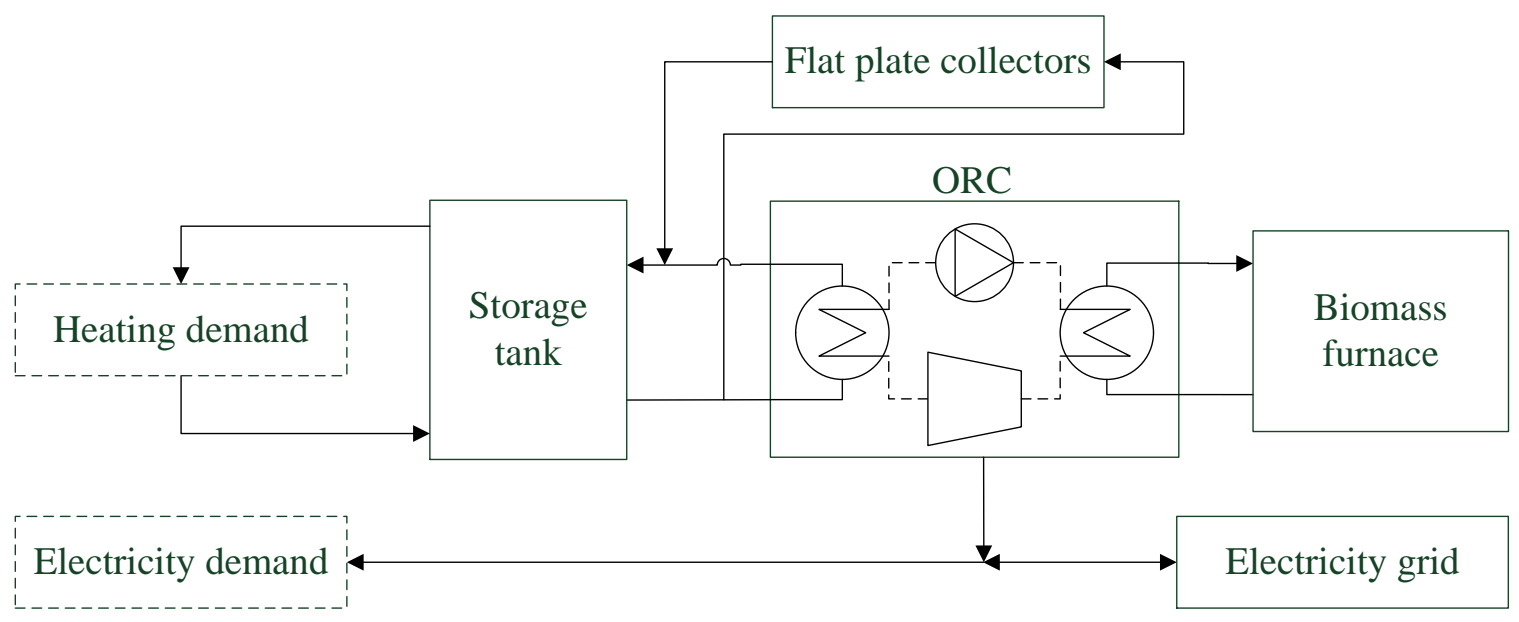

Figure 12: Case 'FPC-ORC' with solar flat plate collectors, a biomass burner, and an ORC unit.

\subsection{Methods}

All the case studies are based on a residential community of 100 houses with a total annual thermal energy demand of $1458 \mathrm{MWh}$ and a total annual electrical energy demand of 490 MWh [160-162]. The residential heating system was assumed to have a supply temperature of $75{ }^{\circ} \mathrm{C}$ and a return temperature of $35{ }^{\circ} \mathrm{C}$ [163]. The daily hot water demand was assumed to remain constant throughout the year at $5.43 \mathrm{kWh}$ per house [160]. The 
annual space heating demand was assumed to be 12.6 MWh per house [160, 162]. This total demand was distributed over the year depending on the ambient temperature of a typical meteorological year. The daily electricity demand was assumed on an average to be $13.42 \mathrm{kWh}$ per house [161].

A solar collector area of $1000 \mathrm{~m}^{2}$ was assumed for both the flat plate and the PV collectors. The chosen area is based on comparable solar district heating plants in Denmark [164], where for each household a $10 \mathrm{~m}^{2}$ to $13 \mathrm{~m}^{2}$ solar collector area is foreseen. This solar collector area is thus seen as being realistically available on open land for a community of 100 houses. The solar collectors were assumed to have a tilt angle of $45^{\circ}$ and faced south. The shading of the solar collectors was neglected while an albedo factor of 0.2 was assumed. For the plant location in Copenhagen, Denmark, the daily PV array output was found using the software PVsyst [165]. The PV array could provide up to $158 \mathrm{kWh} \mathrm{m}^{-2}$ of energy annually after the inverter losses. The solar thermal system was simulated based on flat plate collectors with a constant supply temperature of $75{ }^{\circ} \mathrm{C}$ and a first and second degree heat loss coefficient of $2.5 \mathrm{~W} \mathrm{~m}^{-2} \mathrm{~K}^{-1}$ and $0.015 \mathrm{~W} \mathrm{~m}^{-2} \mathrm{~K}^{-1}$, respectively. The incidence angle modifier was found based on the sun position for every hour assuming an optical efficiency of 0.8. The solar thermal collectors could supply up to $424 \mathrm{kWh} \mathrm{m}^{-2}$ of energy annually. The considered cases do not consider any electrical energy storage since net metering is assumed. For the heat supply, a maximum thermal energy storage of about $15.5 \mathrm{~m}^{3}$ was assumed as a reasonable trade-off between the storage usefulness and cost for the given analysis. The capital investment cost of the storage was assumed to be $4000 € \mathrm{~m}^{-3}$ [166].

The GSHP was modelled with different seasonal COP values accounting for the seasonal changes in the soil temperature. These were estimated to be 2.5 for winter, 2.7 for spring and autumn, and 2.9 for summer months based on the current technologies and soil temperature [167-169]. Electricity for the heat pump was supplied from grid in case of insufficient electricity generation from the solar PV system. The electricity for the heat pump was assumed to have a reduced tax rate in order to ensure that the taxes per $\mathrm{kWh}$ of heat supplied are not higher than those from fossil sources [170]. The biomass boiler was assumed to operate with wood pellets. The conversion efficiency based on the lower heating value 
was estimated for an automated fired system [171]. The ORC unit, using the energy from the biomass boiler, converted the heat to electricity with an assumed average efficiency of $18 \%$ [172]. The ORC unit was sized such that it could satisfy the highest heat demand on a day for up to 12 hours. For the present analysis, this corresponded to a net power output of about $175 \mathrm{~kW}_{\mathrm{e}}$. For such an ORC unit, the cost overviews provided by Quoilin et al. [173] and Lemmens [174] suggested specific installed costs at approximately $6000 € \mathrm{~kW}_{\mathrm{e}}^{-1}$ and $4000 € \mathrm{~kW}_{\mathrm{e}}^{-1}$, respectively. The study by Duvia et al. [175] suggested a higher specific price at $10200 € \mathrm{~kW}_{\mathrm{e}}^{-1}$ for a $345 \mathrm{~kW}_{\mathrm{e}}$ ORC unit. Based on this, a specific investment cost of $8000 € \mathrm{~kW}_{\mathrm{e}}^{-1}$ (including the biomass system) was selected for the FPC-ORC case. The annual O\&M cost was assumed to be $35 € \mathrm{~kW}_{\mathrm{e}}^{-1}[176]$.

The economic analysis for the case studies was based on a plant lifetime of 30 years. In the analysis, $100 \%$ of the capital investment costs were assumed to be covered by a loan with a loan duration of 20 years and an annual interest rate of $5 \%$ on the debt. All operational expenses, such as fuel costs, were corrected for inflation with an average annual rate of $2 \%$ [177]. The wood pellets were assumed to be carbon neutral. The annualized costs are used as an indicator for the comparison of the different solutions. The annualized cost is composed of two parts: (1) the costs related to the investment and (2) the costs related to the O\&M of the plant. The first part is the sum of the capital investment costs and the total interest payments for the project divided by the project lifetime. The second part comprises of the total net cash flows for O\&M occurring during the lifetime (i.e. the O\&M costs after deducting the revenue from net metering, if any), divided by the project lifetime so as to obtain the annual net O\&M costs. The annualized cost, as the sum of the two parts, thus indicates the amount spent by the system operator on an average annually over the project lifetime. Table 2 shows the other key assumptions for the various cases.

Table 2: Assumptions for the various cases.

\begin{tabular}{lll}
\hline Parameter & Value & Reference \\
\hline
\end{tabular}

Natural gas 
Burner efficiency

0.96

[178]

Lower heating value

$11.0 \mathrm{kWh} \mathrm{Nm}^{-3}$

Higher heating value

$12.2 \mathrm{kWh} \mathrm{Nm}^{-3}$

Burner capital investment cost

$100 € \mathrm{~kW}^{-1}$

Burner annual O\&M cost

$3.7 € \mathrm{~kW}^{-1}$

Natural gas purchase cost

$0.7 € \mathrm{Nm}^{-3}$

$\mathrm{CO}_{2}$ emission factor

$0.205 \mathrm{kgCO}_{2} \mathrm{kWh}^{-1}$

Solar energy

PV array capital investment cost

$1250 € \mathrm{~kW}_{\mathrm{p}}^{-1}$

PV array annual O\&M cost

$12.54 € \mathrm{~kW}_{\mathrm{p}}^{-1}$

Flat plate collectors capital investment cost

$227 € \mathrm{~m}^{-2}$

Flat plate collectors annual O\&M cost

$0.57 € \mathrm{MWh}^{-1}$

GHSP

Capital investment cost

$680 € \mathrm{~kW}_{\mathrm{th}}^{-1}$

Annual O\&M cost

$5.5 € \mathrm{~kW}_{\mathrm{th}}^{-1}$

\section{Biomass}

Burner efficiency

0.92

Burner capital investment cost

$400 € \mathrm{~kW}_{\mathrm{th}}^{-1}$

Burner annual O\&M cost

$2.7 € \mathrm{MWh}^{-1}$

Wood pellets lower heating value

$16.8 \mathrm{MJ} \mathrm{kg}^{-1}$

Wood pellets moisture content

8.7 wt $\%$

Wood pellets purchase cost

$0.16 € \mathrm{~kg}^{-1}$

Grid electricity

Purchase cost

$0.22 € \mathrm{kWh}^{-1}$

$\mathrm{CO}_{2}$ emission factor

$0.326 \mathrm{kgCO}_{2} \mathrm{kWh}^{-1}$ 


\subsection{Results and discussion}

The capital investment costs, the annual net O\&M costs (after deducting the revenue from net metering, if any), and the annualized costs for the considered cases are shown in Fig. 13. It may be observed that the required capital investment cost for the renewable solutions is much higher than that for the base case. The costs for the solar installation have a share of $11 \%$ in the FPC-ORC case and $30 \%$ in the FPC-BIO case. With the heat pumps, the solar field with solar PV panels (PV-HP) is approximately $77000 €$ cheaper than the solar field with flat plate collectors (FPC-HP). For the heat pump cases, the annualized cost for the PV-HP case is slightly lower than for the FPC-HP case. This is because the PV-HP case has a lower capital investment cost than the FPC-HP case. At the same time, the electricity demand from the grid is lower as a part of the demand is covered by the solar PV array, thereby resulting in a lower net O\&M cost. Comparing the annualized costs over the project lifetime, the lowest costs were for the two solar-biomass hybrid plants (FPC-BIO and FPC-ORC). The heat pump solutions have the highest costs, as the price for electricity is considerable. For any solar-heat pump solution to be more profitable than the base case, the price of electricity must go below $0.17 € \mathrm{kWh}^{-1}$ for the PV-HP case and below $0.15 € \mathrm{kWh}^{-1}$ for the FPC-HP case. The cost of the solar collectors have only little influence on the annualized costs for the heat pump solutions as they are overshadowed by the heat pump capital investment cost and the operating cost.

The lowest annualized cost is achieved with the FPC-BIO system closely followed by the FPC-ORC system. In the case where an existing natural gas fired district heating plant is to be exchanged with a sustainable solution, e.g. a biomass based plant, the results indicate that the FPC-BIO solution is preferable from an economic point of view. However, the current Danish legislation does in many cases prohibit this change if the new plant produces only heat [187]. On the other hand, it is possible to replace a natural gas fired district heating plant with a biomass based CHP plant. In this case the FPC-ORC is the more economically attractive solution, achieving a $9 \%$ lower annualized cost than the base case.

The capital investment cost of the FPC-ORC system is significantly higher than the other considered technologies. This is partly due to the rated capacity of the ORC unit which is 
below $200 \mathrm{~kW}$. This capacity corresponds to the smallest CHP systems offered by ORC unit suppliers. By considering a larger capacity ORC unit the specific capital investment cost of the plant reduces dramatically. For example, if a case with 1000 houses is considered, the capacity of the ORC unit would be around $1750 \mathrm{~kW}$. For CHP ORC units in this power range, Quoilin et al. [173] report a specific total investment below $3000 € \mathrm{~kW}_{\mathrm{e}}^{-1}$. Similarly, Duvia et al. [175] report a value of $4500 € \mathrm{~kW}_{\mathrm{e}}^{-1}$ for a $1803 \mathrm{~kW}_{\mathrm{e}}$ unit. Assuming a case of 1000 houses and a conservative specific capital investment cost of $4000 € \mathrm{~kW}_{\mathrm{e}}^{-1}$ for the ORC unit, while maintaining all the other assumptions same as in Table 2, the results indicate a $28 \%$ lower annualized cost for the FPC-ORC case than the base case. For the FPC-BIO case the annualized cost is $11 \%$ lower than the base case. These results suggest significant economic benefits of the FPC-ORC case for a large capacity plant.

The total annual energy input to the plant by various energy sources and the annual $\mathrm{CO}_{2}$ emissions from the plant are shown in Fig. 14. Of particular interest is to note that even for the solar-biomass hybrid solutions, biomass provides the major share of energy input. This is because of the overall less sunny weather in Denmark and areas with similar climatic conditions. For this reason, it would be interesting to consider long-term storage
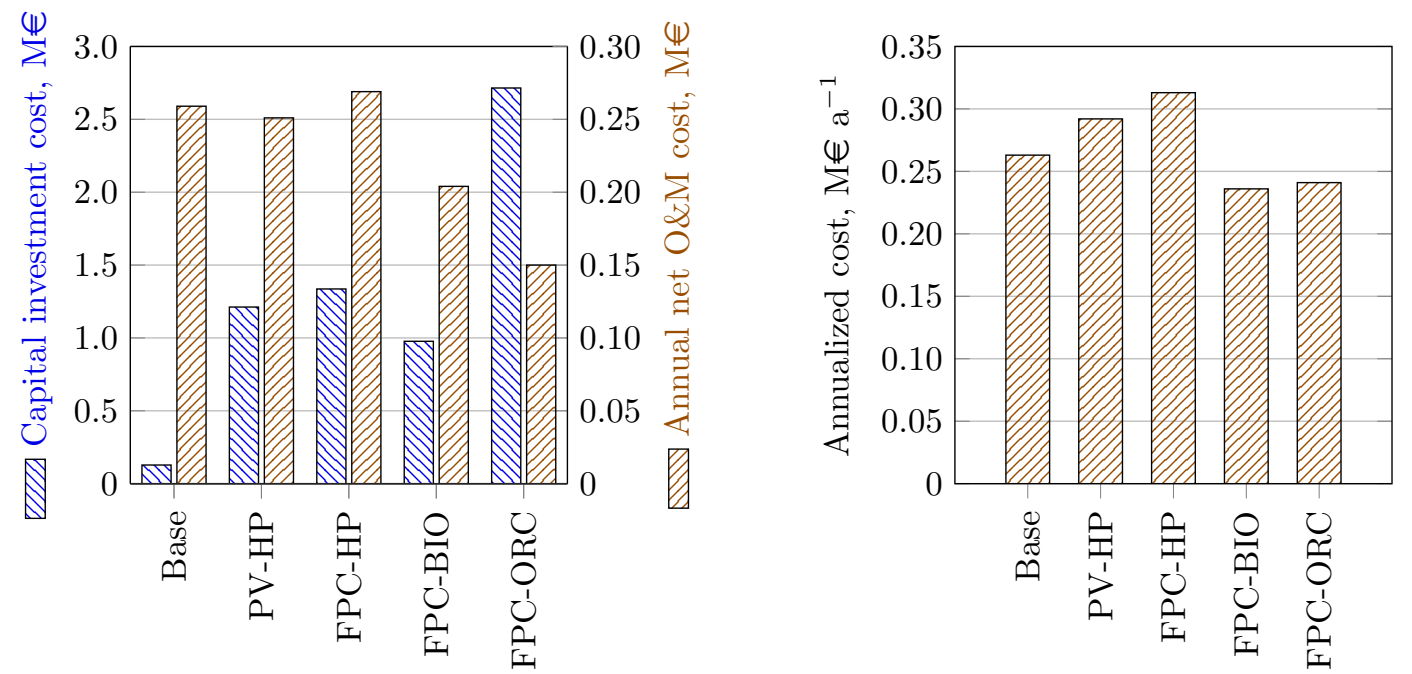

Figure 13: Capital investment costs, annual net O\&M costs, and annualized costs over the plant lifetime for the various cases. 
options such as seasonal storages in order to increase the solar share in the overall energy input mix. The environmental analysis clearly shows that the base case using natural gas and grid electricity has the highest carbon emissions. The cases using the heat pump have the second highest emissions with the biomass solutions having the lowest. In this analysis the current carbon emissions for grid electricity were used which are expected to decrease significantly over the coming decades in Denmark due to the increasing share of wind power and biomass CHP. This would reduce the emissions of the heat pump solutions further.

The results from the sensitivity analysis as shown in Fig. 15 highlight the impact of varying the different parameters on the annualized cost. The solar collector area was varied between $500 \mathrm{~m}^{2}$ and $1500 \mathrm{~m}^{2}$ as compared with the initial assumption of $1000 \mathrm{~m}^{2}$. An overall impact of less than $\pm 5 \%$ on the economic performance of the solar thermal system was observed. The annualized cost increases with increasing solar thermal collector area for the solar thermal cases, whereas it decreases with increasing PV area for the PV based cases. This suggests that larger thermal storage volumes, even seasonal storages, are required to fully offset the heat produced by solar thermal systems. This is because for PV, net-metering was assumed, thereby resulting in the utilization of all the additional solar energy. On the
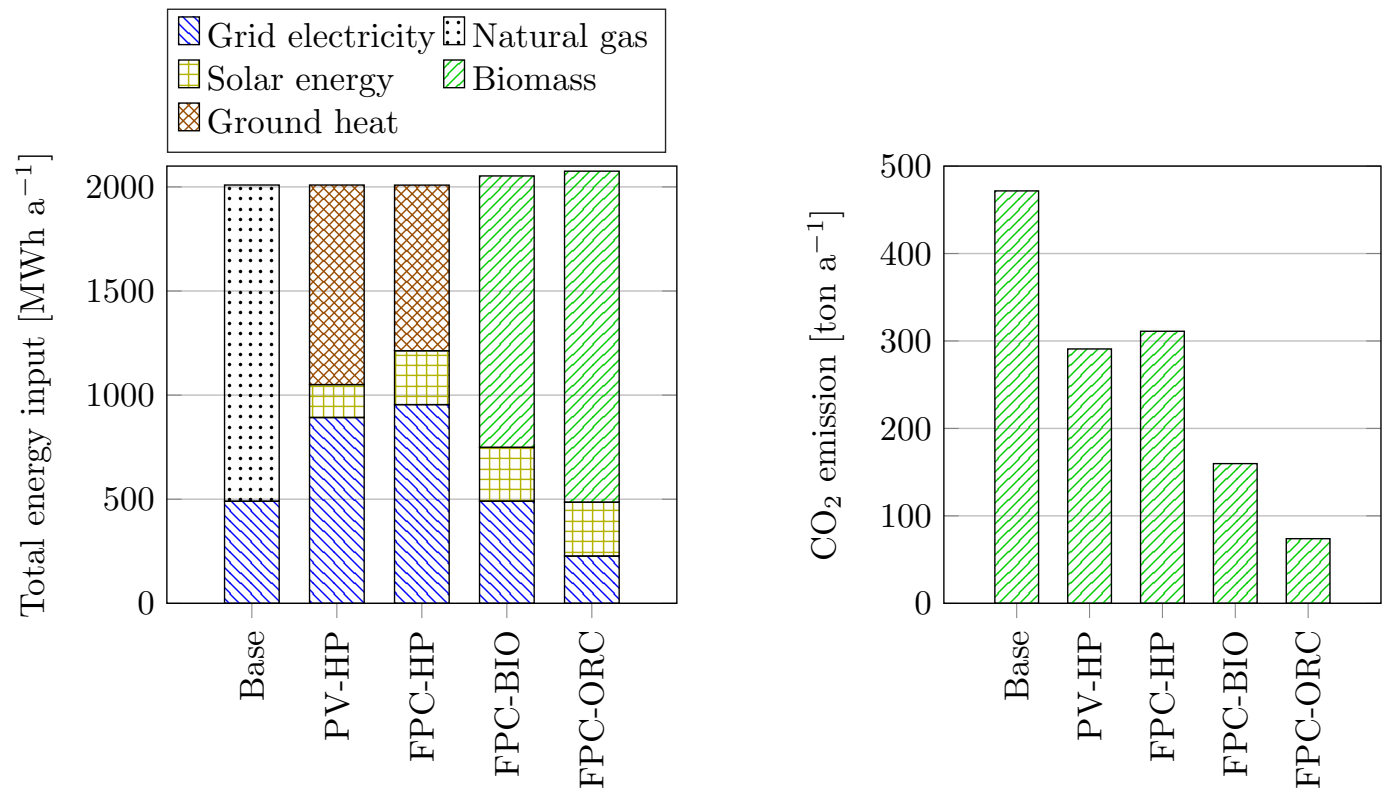

Figure 14: Total energy input by source and total $\mathrm{CO}_{2}$ emissions for each case. 

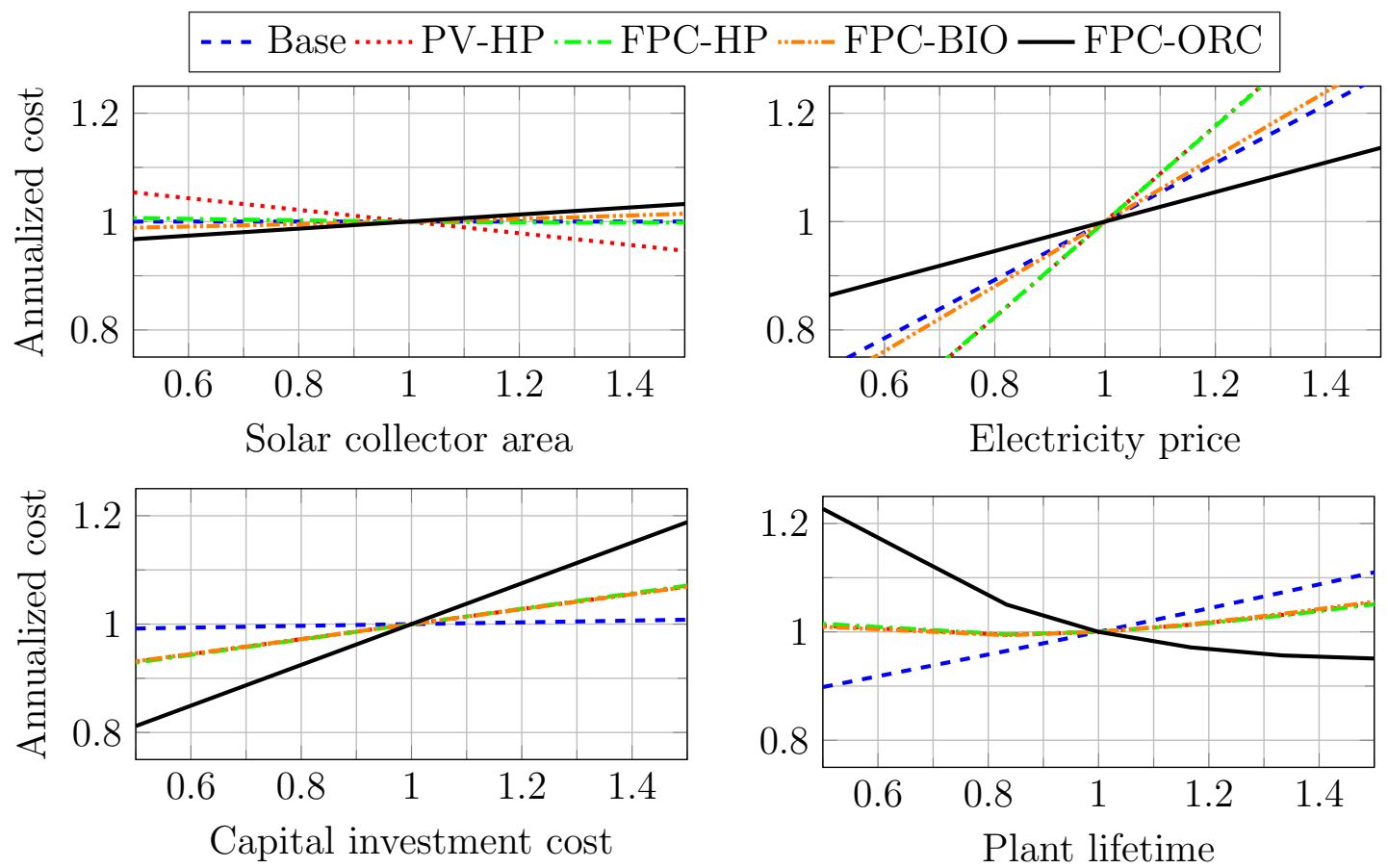

Figure 15: Sensitivity analysis of the impact of the solar collector area, electricity price, investment costs and equipment lifetime on the annualized costs. The values on the plot axes represent the ratio of the changed parameter value to its initial value.

other hand, for the FPC cases, the unused solar energy is present for days with full storages and already satisfied demand, thereby resulting in an overall reduced utilization. This trend is highlighted by the development of annualized costs as they increase with an increase in the solar thermal collector area. The electricity price has a strong influence on the annualized costs. The two heat pump solutions thus have a stronger dependency on the future electricity price than the other cases because of the higher grid electricity demand. An increase in the plant lifetime shows that the annualized cost increases the strongest for the base case as the absence of any renewable energy input buffers the increase in the energy prices. The ORC unit based configuration (FPC-ORC) further shows the influence of the annuities and the loan period at smaller values of the plant lifetimes because of high capital investment cost. As the loan period was set to a maximum of 20 years, but not more than the plant lifetime, the annualized cost decreases rapidly for shorter lifetimes. This is because the distribution of the capital investment costs over the years outweighs the additional costs in terms of the 
loan interest for a longer loan period. A government measure to promote such systems could be to provide investment loans with low interest rates which could encourage fossil energy free solutions.

\section{Research prospects}

Based on the reviewed literature, the following areas are recognized where research for solar energy based heat and power plants may be focused. Among the technical aspects of the solar CHP plants, one of the key research areas is the development of economically attractive designs for the plant components, particularly for small capacities (i.e. from few $\mathrm{kW}$ to few hundreds of $\mathrm{kW}$ ) for residential consumers. Of particular interest are ORC expanders, compact heat exchangers, storage systems, and more efficient solar collectors. Another identified area of research is to develop efficient and effective operation and control algorithms for maximum return on the investment in the plant while considering the local legislation and the electricity and heat market prices. It is also important to analyse the integration of both small and large capacity plants with the existing electricity, district heating, and natural gas grids. From the technoeconomic perspective, it is interesting to develop methods to determine the optimal component sizing for the best economic performance over the plant lifetime. Based on the plant location and local policy advantages, the best combination of the technologies should be decided (e.g. solar PV or thermal, solar-only or solar-hybrid, etc.) Optimization studies should also be conducted in order to identify the thermoeconomically optimal working fluids or fluid mixtures for the various locations and climatic conditions.

From the policy aspect, clear measures should be identified from local, national, and global regulation and legislative perspectives in order to meet the climate and energy targets set by the various governments around the world. The future availability and the cost of fossil fuels as well as the different forms of biomass should be considered in any decision making. Lastly, the social and end-consumer behaviour towards the acceptance of the solar and other renewable energy technologies and the impact of the integration of these technologies with the existing infrastructure must be analysed. This includes, for example, demand side behaviour, indirect benefits from energy efficiency reducing the overall demand, shift in the 
preferred modes of energy consumption (e.g. electric or hydrogen cars instead of fossil fuel based cars), and other similar considerations.

\section{Conclusion}

This paper presents a review of the open literature on solar energy based heat and power plants considering both the solar PV and solar thermal technologies in both solar-only and solar-hybrid configurations. Some key trends observed from the reviewed literature are as follows:

- Fully renewable solar energy based heat and power plants are interesting to study because of their potential to utilize locally available free energy sources and to reduce the consumption of fossil fuels and/or biomass.

- It is important for the solar energy based heat and power plants to follow the dynamic characteristics of the consumer load profiles for reliably satisfying the end-user demands. Solar-only technologies have been found to be incapable of doing so. Some form of hybridization, storage, or backup is necessary.

- It is likely that some supportive policy measures such as green energy targets, public funding, feed-in-tariff, carbon tax, or subsidies will be needed in order for the solar energy based heat and power plants to be able to compete with the fossil fuel alternatives.

Based on the reviewed literature, it is recommended that the research on solar energy based heat and power plants should be focused towards developing economically attractive designs for the various plant components such as expanders for the ORC, compact heat exchangers, storage systems, and more efficient solar collectors, particularly for small capacity systems. Research also needs to be done in order to develop efficient and effective operation and control strategies for a robust year-round performance from the plants. Suitable methods for integration with the current electricity, district heating, and natural gas grids should be developed. Clear policy and legislative measures should be identified and put into 
place so as to promote the sustainable technologies in order to meet the ambitious climate and energy targets set by various governments around the world.

The paper also included some case studies for evaluating the application of solar energy based CHP plants in Denmark. The performed analysis aimed at comparing the overall economic feasibility of these plants for domestic energy supply, an area where a large potential exists in the coming years. The results indicate that it is both economically and environmentally favourable to invest in the solar-biomass hybrid solutions for CHP production for the Danish climatic conditions. This is primarily because biomass is a more attractive option than natural gas, while solar thermal systems allow to reduce the purchased fuel costs. Moreover, in the case of locally available biomass, additional emissions from transporting the fuel may also be avoided. Given the ambitious climate and energy targets of Denmark and the other Nordic countries, solar energy based plants could provide a technically and economically feasible alternative for the combined production of heat and electricity.

\section{Nomenclature}

CHP combined heat and power

COP coefficient of performance

CPVT concentrating photovoltaic-thermal

GSHP ground source heat pump

mCHP micro combined heat and power

O\&M operations and maintenance

ORC organic Rankine cycle

PV photovoltaic

PVT photovoltaic-thermal 


\section{Acknowledgement}

The authors thank Bengt Perers and Simon Furbo, Technical University of Denmark,

Denmark for the useful insights on the installation, operation, and maintenance of solar thermal collectors and district heating plants in the Nordic countries.

\section{Appendix}

The relevant literature is grouped in Tables A.1 to A.5 based on the key technologies employed in the respective studies. 
Table A.1: Power generation technologies and the corresponding studies.

\section{Steam Rankine cycle}

Kolios et al. [55], Norwood et al. [58, 59], Krüger et al. [64], Abdelhady et al. [69], Rabbani et al. [76], Kaushika et al. [98], Mishra et al. [99], Borello et al. [100], Burin et al. [104, 105], Khalid et al. [114], Al-Ali and Dincer [121], Ozlu and Dincer [127], Ghosh and Dincer [151]

$\mathrm{CO}_{2}$ Rankine cycle

Zhang et al. [83-85, 87, 88], Yamaguchi et al. [86], Kuwahara et al. [89], Chen et al. [90]

Ammonia-water cycle

Ozlu and Dincer [74], Yuksel et al. [75], Zamfirescu et al. [112], Hassoun and Dincer [143]

Brayton cycle

Rabbani et al. [76], Hosseini et al. [94], Khalid et al. [114]

\section{Stirling engine}

Crema et al. [60-62], Ferreira et al. [63] Angrisani et al. [113]

\section{Steam engine}

Bouvier et al. [67, 68], Brinkmann [91]

\section{Internal combustion engine}

Zhang et al. [106]

\section{ORC}

Ksayer [57], Al-Sulaiman et al. [65, 66], Almahdi et al. [70], Naccarato et al. [71], Saadatfar et al. [72], Borunda et al. [73], Bocci et al. [77], Baral and Kim [78], Ziviani et al. [79], Twomey et al. [81], Freeman et al. [82], Sterrer et al. [101], Desideri et al. [102], Karellas and Braimakis [103], Ozcan and Dincer [107], Oliveira et al. [109], Jradi et al. [110, 111], Bicer and Dincer [117], Tempesti et al. [118, 119], Ruzzenenti et al. [120], Al-Ali and Dincer [121], Suleman et al. [122], Calise et al. [123, 124], Khalid et al. [128], Ahmadi et al. [129, 130], Islam et al. [134]

Reversible ORC/heat pump systems

Dumont et al. [136], Quoilin et al. [137], Schimpf et al. [138, 139] 
Table A.2: Studies with fuel cells, electrolysers, and/or hydrogen storage tanks.

Shabani et al. [43], Shabani and Andrews [44], Ahmadi et al. [45], Zafar and Dincer [48], Almahdi et al. [70], Ozlu and Dincer [74], Yuksel et al. [75], Calise et al. [80], Hosseini et al. [92-94], Ozcan and Dincer [107], Borello et al. [108], Lacko et al. [125], Rouholamini and Mohammadian [126], Ozlu and Dincer [127], Ahmadi et al. [129, 130], Akikur et al. [131, 132], Islam et al. [134], Assaf and Shabani [135], Shariatzadeh et al. [149]

Table A.3: Studies with energy storage technologies.

Thermal energy storage systems, including thermal storage tanks

Yilmaz et al. [39], Thygesen and Karlsson [42], Auzenet et al. [47], Buonomano et al. [49, 53], Papadopoulos et al. [54], Immovilli et al. [56], Ksayer [57], Krüger et al. [64], Al-Sulaiman et al. [65, 66], Abdelhady et al. [69], Almahdi et al. [70], Naccarato et al. [71], Borunda et al. [73], Ozlu and Dincer [74], Yuksel et al. [75], Bocci et al. [77], Baral and Kim [78], Twomey et al. [81], Calise et al. [80, 95, 96, 97, 116, 123, 124], Borello et al. [100, 108], Ozcan and Dincer [107], Oliveira et al. [109], Zamfirescu et al. [112], Bicer and Dincer [117], Lacko et al. [125], Ozlu and Dincer [127], Khalid et al. [128], Akikur et al. [131, 132], Sanaye and Sarrafi [133], Islam et al. [134], Assaf and Shabani [135], Good et al. [142], Hassoun and Dincer [143]

Compressed air storage system

Hosseini et al. [94]

Batteries and other electrical energy storage systems

Hosseini et al. [93], Efendiev et al. [115], Sanaye and Sarrafi [133], Dagdougui et al. [141], Hassoun and Dincer [143] 
Table A.4: Studies with water purification technologies.

Reverse osmosis

Bocci et al. [77], Ahmadi et al. [129, 130], Ghosh and Dincer [151]

Multiple effect distillation

Norwood and Kammen [59], Calise et al. [95, 96, 97, 116, 124]

Table A.5: Studies with refrigeration, cooling, and heat pump related technologies.

Vapour compression cooling system

Immovilli et al. [56], Karellas and Braimakis [103]

Absorption chiller

Ahmadi et al. [45], Buonomano et al. [53], Papadopoulos et al. [54], Krüger et al. [64], Al-

Sulaiman et al. [65, 66], Almahdi et al. [70], Ozlu and Dincer [74], Yuksel et al. [75], Bocci et al. [77], Hosseini et al. [92], Calise et al. [80, 95, 96, 97, 116, 124], Zhang et al. [106], Ozcan and Dincer [107], Khalid et al. [114], Bicer and Dincer [117], Al-Ali and Dincer [121], Suleman et al. [122], Ozlu and Dincer [127], Khalid et al. [128], Ahmadi et al. [129, 130], Sanaye and Sarrafi [133], Islam et al. [134], Hassoun and Dincer [143], Ghosh and Dincer [151]

\section{Adsorption chiller}

Desideri et al. [102]

\section{Heat pumps}

Franco and Fantozzi [38], Yilmaz et al. [39], Nizetic et al. [40, 41], Thygesen and Karlsson [42], Auzenet et al. [47], Immovilli et al. [56], Almahdi et al. [70], Bicer and Dincer [117], Khalid et al. [128], Islam et al. [134], Good et al. [142] 


\section{References}

[1] J. Twidell, T. Weir, Renewable energy resources, Taylor \& Francis, Abingdon, Oxon, UK, 2nd edn., 2006.

[2] M. S. Guney, Solar power and application methods, Renewable and Sustainable Energy Reviews 57 (2016) 776-785.

[3] G. Manente, High performance integrated solar combined cycles with minimum modifications to the combined cycle power plant design, Energy Conversion and Management 111 (2016) 186-197.

[4] A. Modi, A. Chaudhuri, B. Vijay, J. Mathur, Performance analysis of a solar photovoltaic operated domestic refrigerator, Applied Energy 86 (12) (2009) 2583-2591.

[5] I. Sarbu, C. Sebarchievici, Review of solar refrigeration and cooling systems, 2013.

[6] K. R. Ullah, R. Saidur, H. W. Ping, R. K. Akikur, N. H. Shuvo, A review of solar thermal refrigeration and cooling methods, Renewable and Sustainable Energy Reviews 15 (2013) 499-513.

[7] IEA-ETSAP, IRENA, Solar heat for industrial processes - Technology brief, Tech. Rep., 2015.

[8] B. P. Koirala, B. Ortiz, A. Modi, J. Mathur, N. Kafle, Solar lighting systems delivery models for rural areas in developing countries, in: M. Schäfer, N. Kebir, D. Philipp (Eds.), Micro Perspectives for Decentralized Energy Supply, Berlin, Germany, 268-278, 2011.

[9] Z. Bai, Q. Liu, J. Lei, H. Li, H. Jin, A polygeneration system for the methanol production and the power generation with the solar-biomass thermal gasification, Energy Conversion and Management 102 (2015) 190-201.

[10] M. Ozturk, I. Dincer, Thermodynamic analysis of a solar-based multi-generation system with hydrogen production, Applied Thermal Engineering 51 (1-2) (2013) 1235-1244.

[11] F. Fuso Nerini, F. Valentini, A. Modi, G. Upadhyay, M. Abeysekera, S. Salehin, E. Appleyard, The Energy and Water Emergency Module; A containerized solution for meeting the energy and water needs in protracted displacement situations, Energy Conversion and Management 93 (2015) 205-214.

[12] M. M. Maghanki, B. Ghobadian, G. Najafi, R. J. Galogah, Micro combined heat and power (MCHP) technologies and applications, Renewable and Sustainable Energy Reviews 28 (2013) 510-524.

[13] M. Ali, H. E. S. Fath, P. R. Armstrong, A comprehensive techno-economical review of indirect solar desalination, Renewable and Sustainable Energy Reviews 15 (8) (2011) 4187-4199.

[14] R. Hassanien, E. Hassanien, M. Li, W. Dong, Advanced applications of solar energy in agricultural greenhouses, Renewable and Sustainable Energy Reviews 54 (2016) 989-1001.

[15] J. Mathur, A. Modi, S. Janakiraman, Improving indoor air quality in rural areas using solar and wind energy, in: World Renewable Energy Congress X, WREN, Glasgow, Scotland, 284-289, 2008.

[16] G. Olesen, M. Kvetny, E. la Rovere, Sustainable Energy Vision 2050, URL www.inforse.org/europe/ VisionWorld.htm, accessed: 2015-10-28, 2015. 
[17] OECD, IEA, Energy technology perspectives 2014: Harnessing electricity's potential, Tech. Rep., International Energy Agency, Paris Cedex, France, 2014.

[18] IEA-ETSAP, IRENA, Solar heating and cooling for residential applications - Technology brief, Tech. Rep., 2015.

[19] NORDEN, IEA, Nordic energy technology perspectives: Pathways to a carbon neutral energy future, Tech. Rep., International Energy Agency, Paris Cedex, France, 2013.

[20] Solar District Heating in Europe, SDH, URL www.solar-district-heating.eu, accessed: 2016-0107, 2015.

[21] Marstal Fjernvarme, SUNSTORE4, URL www.sunstore4.eu, accessed: 2016-01-07, 2015.

[22] I. Dincer, C. Zamfirescu, Renewable-energy-based multigeneration systems, International Journal of Energy Research 36 (2012) 1403-1415.

[23] N. T. Raj, S. Iniyan, R. Goic, A review of renewable energy based cogeneration technologies, Renewable and Sustainable Energy Reviews 15 (8) (2011) 3640-3648.

[24] G. Chicco, P. Mancarella, Distributed multi-generation: A comprehensive view, Renewable and Sustainable Energy Reviews 13 (3) (2009) 535-551.

[25] Q. Y. Li, Q. Chen, X. Zhang, Performance analysis of a rooftop wind solar hybrid heat pump system for buildings, Energy and Buildings 65 (2013) 75-83.

[26] S. K. Agrawal, R. Kumar, A. Khaliq, P. Jayaswal, Energy and exergy analyses of a new solar-assisted cogeneration cycle for simultaneous heating and triple effect cooling applications, International journal of Exergy 18 (3) (2015) 275-297.

[27] A. Ghobeity, C. J. Noone, C. N. Papanicolas, A. Mitsos, Optimal time-invariant operation of a power and water cogeneration solar-thermal plant, Solar Energy 85 (9) (2011) 2295-2320.

[28] A. Poullikkas, G. Kourtis, I. Hadjipaschalis, Upscaling of an innovative cogeneration CSP system, Conference Papers in Energy .

[29] R. Shankar, T. Srinivas, Investigation on operating processes for a new solar cooling cogeneration plant, Journal of Solar Energy Engineering 136 (3) (2014) 031016.

[30] R. Shankar, T. Srinivas, Investigation on aqua-ammonia based solar cooling cogeneration plant, Management of Environmental Quality: An International Journal 27 (1) (2016) 36-44.

[31] E. Gençer, M. Tawarmalani, R. Agrawal, Integrated solar thermal hydrogen and power coproduction process for continuous power supply and production of chemicals, in: K. V. Gernaey, J. K. Huusom, R. Gani (Eds.), 12th International Symposium on Process Systems Engineering and 25th European Symposium on Computer Aided Process Engineering, vol. 37, Copenhagen, Denmark, 2291-2296, 2015 .

[32] T. T. Chow, A review on photovoltaic/thermal hybrid solar technology, Applied Energy 87 (2) (2010) 
$365-379$.

[33] T. T. Chow, G. N. Tiwari, C. Menezo, Hybrid solar: A review on photovoltaic and thermal power integration, International Journal of Photoenergy (2012) 1-21.

[34] A. M. Elbreki, M. A. Alghoul, A. N. Al-Shamani, A. A. Ammar, B. Yegani, A. M. Aboghrara, M. H. Rusaln, K. Sopian, The role of climatic-design-operational parameters on combined PV/T collector performance: A critical review, Renewable and Sustainable Energy Reviews 57 (2016) 602-647.

[35] C. Good, Environmental impact assessments of hybrid photovoltaic-thermal (PV/T) systems - A review, Renewable and Sustainable Energy Reviews 55 (2016) 234-239.

[36] P. Mancarella, MES (multi-energy systems): An overview of concepts and evaluation models, Energy 65 (2014) 1-17.

[37] R. S. Kamel, A. S. Fung, P. R. H. Dash, Solar systems and their integration with heat pumps: A review, Energy and Buildings 87 (2015) 395-412.

[38] A. Franco, F. Fantozzi, Experimental analysis of a self consumption strategy for residential building: The integration of PV system and geothermal heat pump, Renewable Energy 86 (2016) 1075-1085.

[39] S. Yilmaz, H. Binici, H. R. Ozcalik, Energy supply in a green school via a photovoltaic-thermal power system, Renewable and Sustainable Energy Reviews 57 (2016) 713-720.

[40] S. Nizetic, D. Coko, I. Marasovic, Experimental study on a hybrid energy system with small- and medium-scale applications for mild climates, Energy 75 (2014) 379-389.

[41] S. Nižetić, N. Duić, A. M. Papadopulos, G. M. Tina, F. Grubišić-Čabo, Energy efficiency evaluation of a hybrid energy system for building applications in a Mediterranean climate and its feasibility aspect, Energy 90 (2015) 1-9.

[42] R. Thygesen, B. Karlsson, Simulation of a proposed novel weather forecast control for ground source heat pumps as a mean to evaluate the feasibility of forecast controls' influence on the photovoltaic electricity self-consumption, Applied Energy 164 (2016) 579-589.

[43] B. Shabani, J. Andrews, S. Watkins, Energy and cost analysis of a solar-hydrogen combined heat and power system for remote power supply using a computer simulation, Solar Energy 84 (1) (2010) 144-155.

[44] B. Shabani, J. Andrews, An experimental investigation of a PEM fuel cell to supply both heat and power in a solar-hydrogen RAPS system, International Journal of Hydrogen Energy 36 (9) (2011) $5442-5452$.

[45] P. Ahmadi, I. Dincer, M. A. Rosen, Transient thermal performance assessment of a hybrid solar-fuel cell system in Toronto, Canada, International Journal of Hydrogen Energy 40 (24) (2015) 7846-7854.

[46] J. J. Michael, S. Iniyan, R. Goic, Flat plate solar photovoltaic-thermal (PV/T) systems: A reference guide, Renewable and Sustainable Energy Reviews 51 (2015) 62-88. 
[47] E. Auzenet, A. Guiavarch, I. Lokhat, F. Claudon, Improving the energy efficiency by coupling of a heat pump and hybrid PV-T panels, REHVA Journal (August) (2013) 32-35.

[48] S. Zafar, I. Dincer, Thermodynamic analysis of a combined PV/T-fuel cell system for power, heat, fresh water and hydrogen production, International Journal of Hydrogen Energy 39 (19) (2014) 9962-9972.

[49] A. Buonomano, G. De Luca, R. D. Figaj, L. Vanoli, Dynamic simulation and thermo-economic analysis of a PhotoVoltaic/Thermal collector heating system for an indoor-outdoor swimming pool, Energy Conversion and Management 99 (2015) 176-192.

[50] Centre for Sustainable Energy systems, CHAPS, URL http://csesdev.cecs.anu.edu.au/chaps $\{\backslash$ _ \}proj, accessed: 2016-01-26, 2016.

[51] O. Z. Sharaf, M. F. Orhan, Concentrated photovoltaic thermal (CPVT) solar collector systems: Part I - Fundamentals, design considerations and current technologies, Renewable and Sustainable Energy Reviews 50 (2015) 1500-1565.

[52] O. Z. Sharaf, M. F. Orhan, Concentrated photovoltaic thermal (CPVT) solar collector systems: Part II - Implemented systems, performance assessment, and future directions, Renewable and Sustainable Energy Reviews 50 (2015) 1566-1633.

[53] A. Buonomano, F. Calise, G. Ferruzzi, L. Vanoli, A novel renewable polygeneration system for hospital buildings: Design, simulation and thermo-economic optimization, Applied Thermal Engineering 67 (12) (2014) 43-60.

[54] A. Papadopoulos, T. Tsoutsos, M. Frangou, K. Kalaitzakis, N. Stefanakis, A. G. Boudouvis, Innovative optics for concentrating photovoltaic/thermal (CPVT) systems - the case of the PROTEAS Solar Polygeneration System, International Journal of Sustainable Energy .

[55] A. J. Kolios, S. Paganini, S. Proia, Development of thermodynamic cycles for concentrated solar power plants, International Journal of Sustainable Energy (2012) 1-19.

[56] F. Immovilli, A. Bellini, C. Bianchini, G. Franceschini, Solar trigeneration for residential applications, a feasible alternative to traditional microcogeneration and trigeneration plants, in: IEEE Industry Applications Society, 2008.

[57] E. B. L. Ksayer, Design of an ORC system operating with solar heat and producing sanitary hot water, Energy Procedia 6 (2011) 389-395.

[58] Z. Norwood, S. Pepe, V. Romanin, D. Kammen, Performance-cost analysis of solar combined heat and power systems, in: ASME 2010 4th International Conference on Energy Sustainability, ASME, Phoe, 27-34, 2010.

[59] Z. Norwood, D. Kammen, Life cycle analysis of distributed concentrating solar combined heat and power: economics, global warming potential and water, Environmental Research Letters 7 (2012) 044016 . 
[60] L. Crema, A. Bozzoli, E. Wackelgard, B. Rivolta, S. Hesse, M. Luminari, D. Hislop, B. Restall, Distributed CHP generation from small size concentrated solar power, in: World Renewable Energy Congress XI, Abu Dhabi, UAE, 2010.

[61] L. Crema, F. Alberti, S. Hesse, M. Luminari, R. Garda, B. Restall, Novel m-CHP generation from small scale concentrated solar power, in: World Renewable Energy Forum, WREF 2012, Including World Renewable Energy Congress XII and Colorado Renewable Energy Society (CRES) Annual Conference, Denver, Colorado, USA, 2012.

[62] L. Crema, F. Alberti, E. Wackelgard, B. Rivolta, S. Hesse, L. Luminari, D. Hislop, B. Restall, Novel system for distributed energy generation from a small scale concentrated solar power, Energy Procedia 57 (2014) 447-456.

[63] A. C. Ferreira, M. L. Nunes, J. C. F. Teixeira, L. A. S. B. Martins, S. F. C. F. Teixeira, Thermodynamic and economic optimization of a solar-powered Stirling engine for micro-cogeneration purposes, Energy $111(2016) 1-17$.

[64] D. Krüger, J. Krüger, S. Sukchai, P. Breitzke, M. Rahbani, H. Schenk, S. Hempel, S. Caf, R. Karthikeyan, K. Hennecke, Solar cogeneration with parabolic trough collectors in TRESERT, in: SolarPACES 2012, 2012.

[65] F. A. Al-Sulaiman, I. Dincer, F. Hamdullahpur, Exergy modeling of a new solar driven trigeneration system, Solar Energy 85 (9) (2011) 2228-2243.

[66] F. A. Al-Sulaiman, F. Hamdullahpur, I. Dincer, Performance assessment of a novel system using parabolic trough solar collectors for combined cooling, heating, and power production, Renewable Energy 48 (2012) 161-172.

[67] J.-L. Bouvier, G. Michaux, P. Salagnac, F. Nepveu, D. Rochier, T. Kientz, Experimental characterisation of a solar parabolic trough collector used in a micro-CHP (micro-cogeneration) system with direct steam generation, Energy 83 (2015) 474-485.

[68] J.-L. Bouvier, G. Michaux, P. Salagnac, T. Kientz, D. Rochier, Experimental study of a micro combined heat and power system with a solar parabolic trough collector coupled to a steam Rankine cycle expander, Solar Energy 134 (2016) 180-192.

[69] S. Abdelhady, D. Borello, E. Tortora, Design of a small scale stand-alone solar thermal co-generation plant for an isolated region in Egypt, Energy Conversion and Management 88 (2014) 872-882.

[70] M. Almahdi, I. Dincer, M. A. Rosen, A new solar based multigeneration system with hot and cold thermal storages and hydrogen production, Renewable Energy 91 (2016) 302-314.

[71] F. Naccarato, M. Potenza, A. De Risi, G. Stigliano, Numerical optimization of an organic rankine cycle scheme for co-generation, International Journal of Renewable Energy Research 4 (2) (2014) 508-518.

[72] B. Saadatfar, R. Fakhrai, T. Fransson, Conceptual modeling of nano fluid ORC for solar thermal 
polygeneration, Energy Procedia 57 (2014) 2696-2705.

[73] M. Borunda, O. A. Jaramillo, R. Dorantes, A. Reyes, Organic Rankine cycle coupling with a parabolic trough solar power plant for cogeneration and industrial processes, Renewable Energy 86 (2016) 651663.

[74] S. Ozlu, I. Dincer, Analysis and evaluation of a new solar energy-based multigeneration system, International Journal of Energy Research (In Press).

[75] Y. E. Yuksel, M. Ozturk, I. Dincer, Thermodynamic performance assessment of a novel environmentally-benign solar energy based integrated system, Energy Conversion and Management 119 (2016) 109-120.

[76] M. Rabbani, T. A. H. Ratlamwala, I. Dincer, Transient energy and exergy analyses of a solar based integrated system, Journal of Solar Energy Engineering 137 (2015) 011010.

[77] E. Bocci, M. Villarini, L. Vecchione, D. Sbordone, A. Di Carlo, A. DellEra, Energy and economic analysis of a residential solar organic Rankine plant, Energy Procedia 81 (2015) 558-568.

[78] S. Baral, K. C. Kim, Thermodynamic modeling of the solar organic Rankine cycle with selected organic working fluids for cogeneration, Distributed Generation \& Alternative Energy Journal 29 (3) (2014) $7-34$.

[79] D. Ziviani, A. Beyene, M. Venturini, Design, analysis and optimization of a micro-CHP system based on organic Rankine cycle for ultralow grade thermal energy recovery, Journal of Energy Resources Technology 136 (2014) 011602.

[80] F. Calise, G. Ferruzzi, L. Vanoli, Transient simulation of polygeneration systems based on PEM fuel cells and solar heating and cooling technologies, Energy 41 (1) (2012) 18-30.

[81] B. Twomey, P. A. Jacobs, H. Gurgenci, Dynamic performance estimation of small-scale solar cogeneration with an organic Rankine cycle using a scroll expander, Applied Thermal Engineering 51 (1-2) (2013) 1307-1316.

[82] J. Freeman, K. Hellgardt, C. N. Markides, Working fluid selection and electrical performance optimisation of a domestic solar-ORC combined heat and power system for year-round operation in the UK, Applied Energy (In Press).

[83] X. R. Zhang, H. Yamaguchi, K. Fujima, M. Enomoto, N. Sawada, Theoretical analysis of a thermodynamic cycle for power and heat production using supercritical carbon dioxide, Energy 32 (2007) 591-599.

[84] X. R. Zhang, H. Yamaguchi, K. Fujima, M. Enomoto, N. Sawada, A feasibility study of $\mathrm{CO}_{2}$-based Rankine cycle powered by solar energy, JSME International Journal 48 (3) (2005) 540-547.

[85] X. R. Zhang, H. Yamaguchi, D. Uneno, K. Fujima, M. Enomoto, N. Sawada, Analysis of a novel solar energy-powered Rankine cycle for combined power and heat generation using supercritical carbon 
dioxide, Renewable Energy 31 (2006) 1839-1854.

[99] A. Mishra, M. N. Chakravarty, N. D. Kaushika, Thermal optimization of solar biomass hybrid cogeneration plants, Journal of Scientific \& Industrial Research 65 (2006) 355-363. 
[100] D. Borello, A. Corsini, F. Rispoli, E. Tortora, A co-powered biomass and concentrated solar power Rankine cycle concept for small size combined heat and power generation, Energies 6 (3) (2013)

[101] R. Sterrer, S. Schidler, O. Schwandt, P. Franz, A. Hammerschmid, Theoretical analysis of the combination of CSP with a biomass CHP-plant using ORC-technology in Central Europe, Energy Procedia 49 (2014) 1218-1227.

[102] A. Desideri, S. Amicabile, F. Alberti, S. Vitali-nari, S. Quoilin, Dynamic modeling and control strategies analysis of a novel small CSP biomass plant for cogeneration applications in building, in: ISES Solar World Congress, Daegu, South Korea, 2015.

[103] S. Karellas, K. Braimakis, Energy-exergy analysis and economic investigation of a cogeneration and trigeneration ORC-VCC hybrid system utilizing biomass fuel and solar power, Energy Conversion and Management 107 (2016) 103-113.

[104] E. K. Burin, L. Buranello, P. L. Giudice, T. Vogel, K. Görner, E. Bazzo, Boosting power output of a sugarcane bagasse cogeneration plant using parabolic trough collectors in a feedwater heating scheme, Applied Energy 154 (2015) 232-241.

[105] E. Burin, T. Vogel, S. Multhaupt, A. Thelen, G. Oeljeklaus, K. Görner, E. Bazzo, Thermodynamic and economic evaluation of a solar aided sugarcane bagasse cogeneration power plant, Energy (In Press).

[106] X. Zhang, H. Li, L. Liu, R. Zeng, G. Zhang, Analysis of a feasible trigeneration system taking solar energy and biomass as co-feeds, Energy Conversion and Management 122 (2016) 74-84.

[107] H. Ozcan, I. Dincer, Thermodynamic analysis of an integrated SOFC, solar ORC and absorption chiller for tri-generation applications, Fuel Cells 13 (5) (2013) 781-793.

[108] D. Borello, S. Evangelisti, E. Tortora, Modelling of a CHP SOFC system fed with biogas from anaerobic digestion of municipal waste integrated with solar collectors and storage unit, International Journal of Thermodynamics 16 (1) (2013) 28-35.

[109] A. Oliveira, A. Palmero-Marrero, J. Soares, P. Horta, J. Brouwer, C. Saraiva, H. Frej, E. G. Bennouna, S. Lalami, Presentation and preliminary simulation of a biomass/solar micro-cogeneration ORC system, in: 13th International Conference on Sustainable Energy Technologies, Geneva, Switzerland, 2014.

[110] M. Jradi, S. Riffat, Modelling and testing of a hybrid solar-biomass ORC-based micro-CHP system, International Journal of Energy Research 38 (2014) 1039-1052.

[111] M. Jradi, J. Li, H. Liu, S. Riffat, Micro-scale ORC-based combined heat and power system using a novel scroll expander, International Journal of Low-Carbon Technologies 9 (2) (2014) 91-99.

[112] C. Zamfirescu, I. Dincer, M. Stern, W. R. Wagar, Exergetic, environmental and economic analyses of 
small-capacity concentrated solar-driven heat engines for power and heat cogeneration, International Journal of Energy Research 36 (2012) 397-408.

[113] G. Angrisani, K. Bizon, R. Chirone, G. Continillo, G. Fusco, S. Lombardi, F. S. Marra, F. Miccio, C. Roselli, M. Sasso, R. Solimene, F. Tariello, M. Urciuolo, Development of a new concept solarbiomass cogeneration system, Energy Conversion and Management 75 (2013) 552-560.

[114] F. Khalid, I. Dincer, M. A. Rosen, Energy and exergy analyses of a solar-biomass integrated cycle for multigeneration, Solar Energy 112 (2015) 290-299.

[115] A. M. Efendiev, Y. E. Nikolaev, D. P. Evstaf, Opportunities of energy supply of farm holdings on the basis of small scale renewable energy sources, Thermal Engineering 63 (2) (2016) 114-121.

[116] F. Calise, A. Cipollina, M. D. D'Accadia, A. Piacentino, A novel renewable polygeneration system for a small Mediterranean volcanic island for the combined production of energy and water: Dynamic simulation and economic assessment, Applied Energy 135 (2014) 675-693.

[117] Y. Bicer, I. Dincer, Analysis and performance evaluation of a renewable energy based multigeneration system, Energy 94 (2016) 623-632.

[118] D. Tempesti, G. Manfrida, D. Fiaschi, Thermodynamic analysis of two micro CHP systems operating with geothermal and solar energy, Applied Energy 97 (2012) 609-617.

[119] D. Tempesti, D. Fiaschi, Thermo-economic assessment of a micro CHP system fuelled by geothermal and solar energy, Energy 58 (2013) 45-51.

[120] F. Ruzzenenti, M. Bravi, D. Tempesti, E. Salvatici, G. Manfrida, R. Basosi, Evaluation of the environmental sustainability of a micro CHP system fueled by low-temperature geothermal and solar energy, Energy Conversion and Management 78 (2014) 611-616.

[121] M. Al-Ali, I. Dincer, Energetic and exergetic studies of a multigenerational solar-geothermal system, Applied Thermal Engineering 71 (1) (2014) 16-23.

[122] F. Suleman, I. Dincer, M. Agelin-Chaab, Development of an integrated renewable energy system for multigeneration, Energy 78 (2014) 196-204.

[123] F. Calise, D. Capuano, L. Vanoli, Dynamic simulation and exergo-economic optimization of a hybrid solar-geothermal cogeneration plant, Energies 8 (2015) 2606-2646.

[124] F. Calise, M. D. D'Accadia, A. MacAluso, A. Piacentino, L. Vanoli, Exergetic and exergoeconomic analysis of a novel hybrid solar-geothermal polygeneration system producing energy and water, Energy Conversion and Management 115 (2016) 200-220.

[125] R. Lacko, B. Drobnič, M. Mori, M. Sekavčnik, M. Vidmar, Stand-alone renewable combined heat and power system with hydrogen technologies for household application, Energy 77 (2014) 164-170.

[126] M. Rouholamini, M. Mohammadian, Energy management of a grid-tied residential-scale hybrid renewable generation system incorporating fuel cell and electrolyzer, Energy and Buildings 102 (2015) 
$406-416$.

[127] S. Ozlu, I. Dincer, Development and analysis of a solar and wind energy based multigeneration system, Solar Energy 122 (2015) 1279-1295.

[128] F. Khalid, I. Dincer, M. A. Rosen, Techno-economic assessment of a renewable energy based integrated multigeneration system for green buildings, Applied Thermal Engineering 99 (2016) 1286-1294.

[129] P. Ahmadi, I. Dincer, M. A. Rosen, Multi-objective optimization of a novel solar-based multigeneration energy system, Solar Energy 108 (2014) 576-591.

[130] P. Ahmadi, I. Dincer, M. A. Rosen, Performance assessment of a novel solar and ocean thermal energy conversion based multigeneration system for coastal areas, Journal of Solar Energy Engineering 137 (2015) 011013.

[131] R. K. Akikur, R. Saidur, H. W. Ping, K. R. Ullah, Performance analysis of a co-generation system using solar energy and SOFC technology, Energy Conversion and Management 79 (2014) 415-430.

[132] R. K. Akikur, R. Saidur, K. R. Ullah, S. A. Hajimolana, H. W. Ping, M. A. Hussain, Economic feasibility analysis of a solar energy and solid oxide fuel cell-based cogeneration system in Malaysia, Clean Technologies and Environmental Policy (In Press).

[133] S. Sanaye, A. Sarrafi, Optimization of combined cooling, heating and power generation by a solar system, Renewable Energy 80 (2015) 699-712.

[134] S. Islam, I. Dincer, B. S. Yilbas, Energetic and exergetic performance analyses of a solar energybased integrated system for multigeneration including thermoelectric generators, Energy 93 (2015) $1246-1258$.

[135] J. Assaf, B. Shabani, Transient simulation modelling and energy performance of a standalone solarhydrogen combined heat and power system integrated with solar-thermal collectors, Applied Energy 178 (2016) 66-77.

[136] O. Dumont, S. Quoilin, V. Lemort, Experimental investigation of a reversible heat pump/organic Rankine cycle unit designed to be coupled with a passive house to get a Net Zero Energy Building, International Journal of Refrigeration 54 (2015) 190-203.

[137] S. Quoilin, O. Dumont, K. H. Hansen, V. Lemort, Design, modeling, and performance optimization of a reversible heat pump/organic Rankine cycle system for domestic application, Journal of Engineering for Gas Turbines and Power 138 (1) (2016) 011701.

[138] S. Schimpf, K. Uitz, R. Span, Simulation of a solar assisted combined heat pump - Organic Rankine Cycle system, Energy Conversion and Management 102 (2015) 3937-3944.

[139] S. Schimpf, R. Span, Techno-economic evaluation of a solar assisted combined heat pump - Organic Rankine Cycle system, Energy Conversion and Management 94 (2015) 430-437.

[140] D. H. W. Li, L. Yang, J. C. Lam, Zero energy buildings and sustainable development implications - 
A review, Energy 54 (2013) 1-10.

[141] H. Dagdougui, R. Minciardi, A. Ouammi, M. Robba, R. Sacile, Modeling and optimization of a hybrid system for the energy supply of a "Green" building, Energy Conversion and Management 64 (2012) 351-363.

[142] C. Good, I. Andresen, A. G. Hestnes, Solar energy for net zero energy buildings A comparison between solar thermal, PV and photovoltaic-thermal (PV/T) systems, Solar Energy 122 (2015) 986-996.

[143] A. Hassoun, I. Dincer, Analysis and performance assessment of a multigenerational system powered by Organic Rankine Cycle for a net zero energy house, Applied Thermal Engineering 76 (2015) 25-36.

[144] A. C. Oliveira, A novel solar facade concept for energy polygeneration in buildings, International Journal of Low Carbon Technologies .

[145] S. A. Omer, D. G. Infield, Design and thermal analysis of a two stage solar concentrator for combined heat and thermoelectric power generation, Energy Conversion and Management 41 (7) (2000) 737-756.

[146] N. Miljkovic, E. N. Wang, Modeling and optimization of hybrid solar thermoelectric systems with thermosyphons, Solar Energy 85 (11) (2011) 2843-2855.

[147] M. H. Nia, A. A. Nejad, A. M. Goudarzi, M. Valizadeh, P. Samadian, Cogeneration solar system using thermoelectric module and fresnel lens, Energy Conversion and Management 84 (2014) 305-310.

[148] K. S. Ong, Review of solar, heat pipe and thermoelectric hybrid systems for power generation and heating, International Journal of Low-Carbon Technologies .

[149] O. J. Shariatzadeh, A. H. Refahi, S. S. Abolhassani, M. Rahmani, Modeling and optimization of a novel solar chimney cogeneration power plant combined with solid oxide electrolysis/fuel cell, Energy Conversion and Management 105 (2015) 423-432.

[150] J. W. Schwede, I. Bargatin, D. C. Riley, B. E. Hardin, S. J. Rosenthal, Y. Sun, F. Schmitt, P. Pianetta, R. T. Howe, Z.-X. Shen, N. A. Melosh, Photon-enhanced thermionic emission for solar concentrator systems, Nature Materials 9 (9) (2010) 762-767.

[151] S. Ghosh, I. Dincer, Development and analysis of a new integrated solar-wind-geothermal energy system, Solar Energy 107 (2014) 728-745.

[152] C. Good, H. Persson, Ø. Kleven, W. Sulkowski, K. Ellingsen, T. Boström, Solar cells above the Arctic circle - Measuring characteristics of solar panels under real operating conditions, in: 24th European Photovoltaic Solar Energy Conference, Hamburg, Germany, 21-25, 2009.

[153] Ø. Kleven, H. Persson, C. Good, W. Sulkowski, T. Boström, Solar cells above the arctic circle - A comparison between a two-axis tracking system and simulations, in: 24th European Photovoltaic Solar Energy Conference, Hamburg, Germany, 4090-4093, 2009.

[154] C. Good, H. Persson, Ø. Kleven, M. Norton, T. Boström, Towards cost-efficient grid-connected PV power plants in Northern Scandinavia, in: 26th European Photovoltaic Solar Energy Conference, 
Hamburg, Germany, 2011. tem, URL www.iea-etsap.org/web/Workshop/Sophia\{\_\}Antipolis\{\_\}0ct2015/15ResidentialheatpumpsinthefutureDanishenergysystem.pdf, accessed: 2016-02-09, 2016.

[169] T. Vangkilde-Pedersen, C. Ditlefsen, A. L. Højberg, Shallow geothermal energy in Denmark, Geological 
Survey of Denmark and Greenland Bulletin 26 (2012) 37-40.

[170] SKAT, Tax exemption with heat pumps in Denmark, URL www.skat.dk/SKAT . aspx?oID=2061615, accessed: 2016-02-09, 2016.

[171] P. Quaak, H. Knoef, H. Stassen, Energy from biomass: A review of combustion and gasification technologies, World Bank Publications 23.

[172] R. Bini, M. Di Prima, A. Guercio, Organic Rankine cycle (ORC) in biomass plants: An overview on different applications, 2010.

[173] S. Quoilin, M. V. D. Broek, S. Declaye, P. Dewallef, V. Lemort, Techno-economic survey of Organic Rankine Cycle (ORC) systems, Renewable and Sustainable Energy Reviews 22 (2013) 168-186.

[174] S. Lemmens, A perspective on costs and cost estimation techniques for organic Rankine cycle systems, in: The 3rd International Seminar on ORC Power Systems, Brussels, Belgium, 2015.

[175] A. Duvia, A. Guercio, C. R. di Schio, Technical and economic aspects of biomass fuelled CHP plants based on ORC turbogenerators feeding existing district heating networks, 2009.

[176] I. Peretti, Biomass CHP systems using ORC from Europe to North America, URL www. biomassconference.com/files/docs/2015/Peretti\{\_\}Ilaria.pdf, 2015.

[177] Energistyrelsen, Samfundsøkonomiske beregningsforudsætninger, URL www.ens.dk/info/tal-kort/ fremskrivninger-analyser-modeller/samfundsokonomiske-beregnings-forudsaetninger, accessed: 2016-02-09, 2016 .

[178] ELFORSK, De blå håndbøger, URL http://www.elforsk.dk/Denlille\{\_\}storeblaa.aspx, accessed: 2016-02-09, 2016.

[179] HMN GasNet, Brugerbetaling or gebyrer, URL http://gasnet.dk/priserogbetingelser/ brugerbetalingoggebyrer/, accessed: 2016-02-09, 2016.

[180] GasprisGuiden, Gaspris, URL www.gasprisguiden.dk, accessed: 2016-02-09, 2016.

[181] National Environmental Research Institute, Danish emission inventories for stationary combustion plants, URL http://www2.dmu.dk/1\{\_\}viden/2\{\_\}Publikationer/3\{\_\}arbrapporter/ rapporter/AR200 . pdf, accessed: 2016-02-09, 2004.

[182] C. Verhoest, Y. Ryckmans, Industrial wood pellets: Report, URL www.enplus-pellets.eu/wpcontent/uploads/2012/04/Industrial-pellets-report\{\_\}PellCert\{\_\}2012\{\_\}secured. pdf, accessed: 2016-02-09, 2012.

[183] Ea Energianalyse, Wazee, Opdatering af samfundsøkonomiske brændselspriser: Biomasse, URL www. ea-energianalyse.dk/reports/1065\{\_\}opdatering $\left\{\backslash_{-}\right\}$af $\left\{\backslash_{-}\right\}$samfundsoekonomiske $\left\{\backslash_{-}\right.$ \}braendselspriser\{\_\}biomasse.pdf, accessed: 2016-02-09, 2011.

[184] PricewaterhouseCoopers, Samlet overblik over afregning og godtgørelse af afgifter, URL www.pwc.dk/ da/afgifter/assets/pwc-afgiftsvejledning-2015.pdf, accessed: 2016-02-09, 2015. 
[185] NRGi NET, Elpriser, URL www.nrginet.dk/privat/privat/priser-og-gebyrer/elpriser/, accessed: 2016-02-09, 2016 .

[186] Energinet DK, Less CO2 emission from electricity consumption in 2014, URL www.energinet.dk/ EN/KLIMA-OG-MILJOE/Nyheder/Sider/Mindre-C02-udledning-fra-elforbrug-i-2014.aspx, accessed: 2016-02-09, 2015.

[187] Energistyrelsen, Omlægning til afgiftsfrie brændsler, URL www.ens.dk/undergrund-forsyning/elnaturgas-varmeforsyning/forsyning-varme/regulering/omlaegning-afgiftsfrie, accessed: 2016-02-20, 2016. 